\title{
Managed Process, Due Care: Structures of Accountability in Health Care
}

\author{
Nan D. Hunter, J.D.*
}

\section{INTRODUCTION}

Almost unnoticed, a new kind of adjudication system has appeared in American law. In forty-one states and the District of Columbia, special entities have been established to resolve contract and tort claims. State law created and mandates each system; these are not arbitrations agreed to by contract between the parties. Despite their public nature, however, these systems are not offered or operated by courts; the public function of adjudication is entirely outsourced to private actors. The decision-makers are neither elected nor appointed, nor are they public sector employees; they work in private companies. Most do not write opinions, and they neither establish nor follow precedent.

These new entities are the external review systems set up to resolve disputes between patients and managed care organizations (MCOs), which arise when such organizations deny coverage for medical treatment, services, or equipment that the patient, generally upon the recommendation of a physician, believes to be medically necessary. When pre-authorization for care is required, the coverage decision about whether to pay also becomes in effect a treatment decision that determines whether the care will ever be rendered. The payor's decision merges with and trumps what used to be solely the treating physician's decision. It is this massive shift in the ramifications of these disputes that has caused lawmakers to pay much greater attention to the processes for resolving them.

This Article examines how legal, political, and economic change produced a new adjudicatory mechanism for resolving disputes between patients and MCOs. It is in essence a case study of the multiple determinants of procedure in a particular field-health law-at a time of rapid change in the underlying

* Professor of Law and Co-Director, Center for Health, Science and Public Policy, Brooklyn Law School. I received support for the writing of this Article from the Brooklyn Law School Summer Research Program. Robin Fukuyama, Melissa Gable, and Emily Kern provided excellent research assistance. Many thanks for feedback and support to Sylvia Law and, especially, Chai Feldblum. 
industry. We will see how these changes, plus a broader cultural shift toward less acceptance of professional omniscience, are reshaping our core concepts of medical decision-making in an increasingly corporate environment. Through close analysis of this example, we can also learn a significant amount about newly-emerging models of procedural justice.

The Article proceeds in the following steps: Part I describes the complex cluster of issues implicated in the adjudicatory procedures for health-care-related disputes. These cases are extraordinarily rich in consequences, because they concern two issues in addition to procedures for dispute resolution: the allocation of health care resources and the quality of medical care. Part II analyzes the external review systems in the context of what $I$ call health process exceptionalism: the unexamined seesaw between principles of due process and the tradition of deference to medical authority in health law decision-making systems. It explores the curious way in which deference to medical judgment substituted for the structural protections of procedural due process and then, in a kind of doctrinal blowback, how due process norms came to trump deference. It places the new external review laws in that context, as reflecting the ascendancy of a due process model. Part III describes the new external review adjudication systems that have emerged from these reform campaigns, focusing on their procedural law components (such as scope of jurisdiction, standards of review, and remedies) and their legislative and political histories. It then applies due process criteria to these systems. I argue that these laws fully satisfy neither the due process nor the deference paradigm, nor are they likely to enhance the quality of medical care, but instead reflect the trend to hybrid public-private institutions in law and governance.

Part IV of the Article asks how changes in health law relate to issues raised by broader theories of process. Traditionally, a focus on the right to a hearing prior to a deprivation of liberty or property held center court in process discourse. I argue that external review systems signal the emergence of new process values in procedural due process theory. In the context of private sector disputes, rather than challenges to actions of the government, accountability carries greater significance as a process value than does the right to a hearing. This Part seeks to reinvigorate the theoretical foundations for procedural due process, an area largely abandoned since debates over dignitarian values in process petered out in the late 1970s. Finally, Part V applies process values to external review systems and concludes that there is no persuasive evidence that they have achieved the primary function for which they were created, i.e., providing accountability. I then return to the phenomenon of health process exceptionalism to analyze its future directions. 


\section{HEALTH, LAW, AND PROCESS}

When one considers the process aspects of health law, important questions abound. Should the resolution of disputed medical issues in law be delegated to professional experts, or resolved by traditional adjudicatory methods? Who should determine which medical issues get decided in which way? Should it depend on the medical characteristics of the particular issue or on the nature of the legal questions presented? Are the individuals whose treatment is at issue to be conceptualized as rights-bearing autonomous citizens or as semi-dependent patients to whom fiduciary duties are owed? Each of these questions arises at the individual case level, and also carries broader ramifications. At the individual level, resolutions of health care disputes implicate bodily integrity and autonomy concerns as well as major financial consequences. At the societal level, the concerns resonate with broad normative echoes, as well as huge costs.

Conceptualizing the process aspects of health law at the systemic level, however, presents an even thornier set of problems. Perhaps more so than in any other field, health law process questions reverberate with policy ramifications in multiple and divergent realms. The design and operation of an optimal process for resolving health-related disputes implicates three arenas of policy-making:

(1) The processes by which health-related disputes are decided requires articulation of, and choices among, various norms of procedure. One finds in procedure theory a rich debate among proponents of models emphasizing dignitarian, accuracy, or efficiency goals. Considering the relationship among these models in a health care context is a daunting challenge because of the technical nature of many of the questions involved.

(2) Because the context is health care, enormous social concern attaches to quality control issues, a concern which affects the structure of decision-making procedures. Not only must a procedural system be designed to achieve maximum accuracy in any given case, but the overall impact of how disputed questions about what is proper treatment are decided, across many cases, should operate to improve standards of care across the board.

(3) Finally, the impact of the economics of health care far exceeds that of most kinds of cost-benefit outcome assessments. Determinations about whether certain treatments fall within the range of what is considered standard medical care constitute direct allocation of health care resources. The law of medicine not only governs standards for the care of individual sick people, but also controls the distribution of massive benefits and burdens. Review of managed care treatment denial decisions amounts to review of rationing 
choices made at the level of individual cases.

To engage in a full-scale consideration of the process side of health law leads one into an extraordinary juggling act. Decisions about whether a certain health care service is medically necessary, and therefore will be covered under an insurance contract, are multiply mixed decisions. Not only are they mixed coverage and treatment decisions (because treatments which are unauthorized are unlikely to be provided), as the Supreme Court has realized, ${ }^{1}$ but they also function as mixed treatment and rationing decisions.

Procedural theorists do not usually engage the issues outlined in points two and three. Nor does the main body of work on either health care financing or quality address questions of the procedures of adjudication. Even within health law, analysis of process models paying simultaneous attention to these three complex sets of issues is rare. Debates on health care reform in 1993 and 1994 generated a burst of writing about the procedural mechanisms of health care systems. ${ }^{2}$ Since then, however, there has been relatively little attention paid to the decision-making procedures for resolving competing claims about whether particular health care treatments are medically necessary, the universal standard for coverage decisions. ${ }^{3}$

1. Pegram v. Herdrich, 530 U.S. 211,229 (2000).

2. Although procedural issues received little attention in the press reports about health care reform proposals, the moment presented an opportunity "to construct an analytic framework based in legal process theory and health policy analysis within which to evaluate mechanisms for resolving individual claims to health care and treatment." Margaret G. Farrell, The Need for a Process Theory: Formulating Health Policy Through Adjudication, 8 J.L. \& HEALTH 201, 202 (1994); see also Mark R. Fondacaro, Toward a Synthesis of Law and Social Science: Due Process and Procedural Justice in the Context of National Health Care Reform, 72 DENV. U. L. REV. 303 (1995); Timothy S. Jost, Administrative Adjudication Under Health Care Reform, 47 ADMIN. L. REV. 425 (1995); Eleanor D. Kinney, Protecting Consumers and Providers Under Health Reform: An Overview of the Major Administrative Law Issues, 5 HeALTH Matrix 83 (1995); Sallyanne Payton, Medical Rationing and the Allocation of Adjudicatory Responsibility Under Comprehensive Health Care Reform in the 103rd Congress: An Administrative Lawyer's Postmortem, 47 ADMIN. L. REV. 381 (1995); Rand E. Rosenblatt, Equality, Entitlement, and National Health Care Reform: The Challenge of Managed Competition and Managed Care, 60 BrooK. L. REV. 105 (1994). Unfortunately, the moment passed.

3. The primary exception is a series of articles by Eleanor Kinney. See Eleanor D. Kinney, Tapping and Resolving Consumer Concerns About Health Care, 26 AM. J.L. \& MED. 335 (2000); Eleanor D. Kinney, Consumer Grievance and Appeal Procedures in Managed Care Plans, 3 HEALTH LAW. 17 (1998); Eleanor D. Kinney, Resolving Consumer Grievances in a Managed Care Environment, 6 HeAlth MATRIX 147 (1996); Eleanor D. Kinney, Procedural Protections for Patients in Capitated Health Plans, 22 AM. J.L. \& MED. 301 (1996). These articles have been compiled into a book: Eleanor DeArman Kinney, Protecting American Health Care Consumers (2002). See also William M. Sage, Managed Care's Crimea: Medical Necessity, 
Moreover, the dynamics of private markets do not mitigate the problems of design, because the health care market is famously dysfunctional in multiple ways. ${ }^{4}$ Complaints about access to health care arise within what is usually a closed delivery system. The nature of health insurance in the United States is such that virtually everyone of working age who has private health insurance purchases it through an employer, as a member of a defined group consisting of that employer's workforce. 5 This situation creates a market context which is fundamentally different from the situation of a consumer of automobiles or houses or appliances, who can make purchases from among a large and changing assortment of sellers.

Even if a plan provides relatively free choice of providers, only very large employers enable individuals to choose from among different insurers. ${ }^{6}$ Among all working age persons with health insurance, roughly half will be limited to a single insurance plan. ${ }^{7}$ They will not have the option to choose a plan offered by a different insurance company, which might have different procedures and policies for determining what is medically necessary. Even those who do have a choice may be unable to obtain the information needed to assess differences between plans in claim adjudication systems. Such a limited market is particularly needful of strong procedural rules to assure that imbalances in power are not abused. ${ }^{8}$

These peculiarities of the health care delivery system produce two important

Therapeutic Benefit, and the Goals of Administrative Process in Health Insurance, 53 DUKE L.J. 597 (2003).

4. The classic and earliest statement is Kenneth J. Arrow, Uncertainty and the Welfare Economics of Medical Care, 53 AM. ECON. REv. 941 (1963). For a succinct point and counter-point analysis, see Frank A. Sloan \& Mark A. Hall, Market Failures and the Evolution of State Regulation of Managed Care, 65 LAW \& CONTEMP. ProBs. 169, 172-83 (2002). Scholars with widely divergent policy philosophies agree on the diagnosis of dysfunction. See, e.g., Clark C. havighurst, health Care Choices: Private Contracts as instruments of Health Reform (1995); Paul Starr, The Logic of Health Care Reform (1992).

5. Wendy K. Mariner, Can Consumer Choice Plans Satisfy Patients? Problems with Theory and Practice in Health Insurance Contracts, 69 BROOK. L. REv. 485, 489 (2004).

6. James Maxwell et al., Corporate Health Care Purchasing Among Fortune 500 Firms, 20 HEALTH AFF. 181 (2001).

7. Jeanne M. Lambrew, The Commonwealth Fund, Issue Brief: "Choice" in Health Care: What Do People Really Want? 8 (2005), available at http://www.cmwf.org/usr_doc/ lambrew_853_choice_ib.pdf; David A. Hyman \& Mark Hall, Two Cheers for Employment-Based Health Insurance, 2 YALE J. HEALTH POL'Y L. \& ETHICS 23, 27 (2001); Thomas Rice et al., Workers and Their Health Care: Free To Choose?, 21 HEALTH AFF. 182 (2002).

8. See discussion of agency costs caused by employer purchasing in Gail B. Agrawal, Resuscitating Professionalism: Self-Regulation in the Medical Marketplace, 66 Mo. L. REv. 341, 370-72(2001). 
results. First, the typical market-based accountability mechanism of supply and demand does not operate well. In other markets, consumers who are dissatisfied with a given product or service can elect to purchase from another manufacturer or vendor if they decide to buy the same kind of item again. If your Dell laptop produces sub-par performance, you can always buy a ThinkPad the next time out, or even switch to Apple. If you encounter problems with your health plan covering a treatment that you will need repeatedly, however, you cannot simply opt out of the plan.

Second, patients' lack of an exit option compounds the vulnerability that individuals involved in such disputes are likely to experience. Disputes over whether insurers will cover a particular course of treatment often arise in the context of expensive treatments, when denial of pre-authorization has the greatest impact on cost containment. ${ }^{9}$ Patients facing such disputes tend to be sufficiently ill that they are not in command of their full faculties and can be especially susceptible to manipulation. Moreover, they are often simply frightened and do not want to expend their limited energy arguing. Even when health care consumers are not ill, deficits in information limit their ability to exercise maximum rationality in making health care decisions. ${ }^{10}$

To some extent, as consumer dismay has translated into market pressures, MCOs have responded to ameliorate these problems. The demand for greater choice of providers has led to the dominance of preferred-provider models, which allow reimbursement of out-of-network physicians with less of a penalty than some other forms of MCOs. ${ }^{11}$ To settle litigation brought by the Texas Attorney General, Aetna agreed to limit the financial incentives it offered to doctors who recommended fewer higher-cost treatments. ${ }^{12}$ Yet it is doubtful that these kinds of adjustments will adequately address the most serious process and equity questions, given that the structure of the market and the power imbalances among market participants remain unchanged.

9. Issues related to hospitalization-including surgery, length of hospital stay, and inpatient mental health treatment-are among the most common bases for external reviews, as well as disputes related to durable medical equipment and pharmaceuticals. Leatrice Berman-Sandler, Independent Medical Review: Expanding Legal Remedies To Achieve Managed Care Accountability, 13 AnNals Health L. 233, 254-55 (2004).

10. Russell Korobkin, The Efficiency of Managed Care "Patient Protection" Laws: Incomplete Contracts, Bounded Rationality, and Market Failure, 85 CORNELL L. REV. 1 (1999). For a comparison of "patients" and "consumers," see Mariner, supra note 5, at 491-95.

11. Jon Gabel et al., Health Benefits in 2004: Four Years of Double-Digit Premium Increases Take Their Toll on Coverage, 23 HEALTH AFF. 200, 205 (2004); James C. Robinson, The End of Managed Care, 285 JAMA 2622, 2623-24 (2001).

12. M. Gregg Bloche \& Peter D. Jacobson, The Supreme Court and Bedside Rationing, 284 JAMA 2776, 2778 n.27 (2000). 
Decisions about whether a treatment will be covered constitute microrationing, with ramifications at multiple levels: for the particular patient, for the profession of health care, and for the society's allocation of resources. ${ }^{13}$ The procedures by which such decisions are made merit much greater attention and analysis than they have yet received. This Article seeks to articulate a new analytic framework for assessing and understanding this area where procedural theory, professional responsibilities, and social values overlap.

The exact dimensions of the problem of denials by MCOs are unknown. According to a public opinion survey conducted by the Kaiser Family Foundation and the Harvard University School of Public Health in 2001, approximately twelve percent of adults with private health insurance report that they have experienced denials of coverage or care. ${ }^{14}$ In a 1998 survey, twentytwo percent of respondents said that they had wanted-but had been unable-to appeal a denied claim to an independent reviewer, and thirteen percent said that they had wanted to sue a health plan for malpractice. ${ }^{15}$ A nationally representative sample of managed care enrollees in 1999 found that less than twenty percent of patients who experienced serious health declines or incurred large unreimbursed expenses because of perceived problems with their health plans filed a formal appeal or grievance. ${ }^{16}$ One federal judge, known for his expertise in procedural justice, described "disputes about the new breed of Health Maintenance Organizations' denials of service and Medicare and Medicaid payments" as being "for many millions, among the most critical of their grievances over what they consider to be denials of substantive rights." 17

The Supreme Court's decision in Rush Prudential HMO, Inc. v. Moran ${ }^{18}$

13. The use of medical necessity decisions as a rationing device occurred prior to the widespread adoption of managed care. See Timothy P. Blanchard, "Medical Necessity " Denials as a Medicare Part B Cost-Containment Strategy: Two Wrongs Don't Make It Right or Rational, 34 ST. Louls U. L.J. 939 (1990). However, the pricing and profit structure of managed care exacerbate the incentives for rationing.

14. Kaiser family Found. \& Harvard Sch. of Pub. Health, National Survey on Consumer Experiences with and Attitudes Toward Health Plans: Key Findings 1 (2001), available at http://www.kff.org/kaiserpolls/pomrl 11704 pkg.cfm.

15. Kaiser Family Found., Kaiser Public Opinion Update 2 (2000).

16. Mark Schlesinger et al., Voices Unheard: Barriers to Expressing Dissatisfaction to Health Plans, 80 MILBANK Q. 709, 731-32 (2002).

17. Jack B. Weinstein, Adjudicative Justice in a Diverse Mass Society, 8 J.L. \& POL'y 385, 400-01 (2000) [hereinafter Weinstein, Adjudicative Justice]. Judge Weinstein is well known for his thoughtful responses to the challenges of adjudicating mass tort cases. See JACK B. WEINSTEIN, individual Justice in MASS TORT Litigations: THE EFFECTS OF Class ACtions, CONSOlidations, ANd OThER MUlti-PARTy DEVICES (1995).

18. 536 U.S. 355 (2002). 
marked a crucial point in the establishment of external review systems as new structures for adjudication of these disputes. In Moran the Court upheld an Illinois law which established a system of independent external review when a managed care organization denied coverage for a treatment. The decision turned on whether the state law was preempted by the Employee Retirement Income Security Act (ERISA), a federal statute governing benefit systems offered by private employers. ${ }^{19}$ The Court ruled that the Illinois law was not preempted by ERISA because it functioned as "insurance regulation"-a categorical exemption from ERISA's preemptive scope for insurers (except for self-insured plans). ${ }^{20}$ The result not only legitimated Illinois's law, but sent at least a conditional goahead signal for other states to pursue external review schemes. ${ }^{21}$

At one level, these state-level external review systems represent an attempt to restore medical authority as the trump card in medical decision-making. The means used, however, is an adjudicatory system, and the consequences of these decisions parallel those of other adjudicatory systems. External review organizations can be the crucial venue in deciding, for example, the medical status of administering a particular treatment for a particular condition, whether denying such treatment would fall below an acceptable standard of care, or whether patients have been adequately apprised of their rights to review within the system.

External review systems offer a fascinating case study of both the jurisprudence of health law and a contemporary undertaking to create rules of procedure. Because they are almost universal, because they are the first new procedural mechanism produced by the ascendancy of managed care, and because recalibrating the role of professional authority is the core of their function, such systems provide a powerful window into the jurisprudence of health law. In addition, external review schemes implicate many of the recurring issues of procedure debates: the tension between expertise and democratic values, the role of specialized courts, the decrease in written decisions, and the truncation of collective action, to name a few.

What has resulted from this undertaking is a public-private adjudication system. External review laws channel appeals from MCO denials to private judging companies via a statutorily established process. They signal the ascension of a market model of adjudication embedded within the architecture of

19. 29 U.S.C. $\S \S 1101-1461(2000)$.

20. 29 U.S.C. $\S 1144$ (b)(2) (2000); see Corporate Health Ins., Inc., v. Tex. Dep't of Ins., 314 F.3d 784, 786 (5th Cir. 2003) (relying on Moran to limit preemption of external review to selffunded ERISA plans).

21. See infra text accompanying notes 166-169 for a discussion of why other external review laws may still be vulnerable to ERISA challenges. 
public law, a fundamentally new form of adjudication, based on a different conception than that underlying the more familiar parallel universe of arbitration.

\section{The History of Health PROCESS EXCEPTIONALISM}

Because health law is a field in which decisions often carry enormous consequences, one would expect that a legally enforceable and externally binding decision about whether certain treatments were medically appropriate would trigger a parallel degree of heightened concern with the procedures by which the decisions were made. But that has not been the case. Instead of especially careful procedures, deference to the judgment of physicians has become instantiated in a variety of legal contexts, creating in effect a distinctly different process paradigm for medical disputes. This has occurred largely because physicians' decisions are presumed to be based solely on the interests of the patient and to have built-in protections against error, thus obviating the need for traditional procedural due process protections. This norm of deference to physician judgment constitutes what I call "health process exceptionalism."

Deference originated as a substantive standard first in tort and then in contract law subfields of health law, and later came to also short-circuit process protections in health law. A range of factors-the economic costs of health care, the institutional structure of managed care systems, patient empowerment movements, ${ }^{22}$ and physicians' stands on controversial issues ${ }^{23}$ - have now coalesced to flip the model, so that the due process concepts associated with procedural protections now operate as a substitute for deference to medical authority.

\section{A. Deference to Medical Authority as Substance and Substitute for Due Process}

Across multiple fields of law, and across public and private law, courts have ceded to medical professionals the authority to decide whether a given treatment for an individual patient is (or was) medically necessary and appropriate. From this practice grew a principle of substantive law, initially in tort, that the law would defer to the reasonable judgments of physicians. However, that substantive

22. Groups of patients, such as AIDS and cancer patients, have begun demanding greater autonomy vis-à-vis the medical establishment, and the Internet has enabled a massive increase in access to medical information. Both of these developments have contributed to widespread medical populism. See generally George J. Annas, The Rights of Patients: The Authoritative ACLU GUide to the Rights OF PATIENTS 3-24, 365-67 (3d ed. 2004).

23. The Supreme Court's view of physicians who perform abortions has shifted dramatically. See Nan D. Hunter, Medicine as Politics: Justice Blackmun, Abortion and the Myth of Independence, 71 BROOK. L. REV. (forthcoming 2006). 
principle spread beyond its initial scope, as courts came to invoke it routinely as a substitute for those procedures considered, as both legal and cultural norms, to constitute "due process." 24

But while judges frequently defer to such medical authority in resolving disputes, they seldom provide a satisfactory analysis as to why such deference is warranted. When one closely examines the justifications that are provided for such deference-a recognition of scientific expertise and a reliance on physicians acting as fiduciaries for their patients-they do not suffice as a rationale for the substitution of deference for due process that has occurred. The point I wish to make is not that judges or juries should be making medical decisions, but that the process aspects of health law deserve careful attention when such decisions extend beyond the realm of medical expertise.

The foundation for deference to medical authority is a well-told story, originating in malpractice law. Beginning in the British common law, the principle that courts should defer to the judgment of doctors became a commonplace feature of torts jurisprudence. ${ }^{25}$ The standard measure for the assessment of malpractice was whether the doctor deviated from practices which were the professional custom in that situation. ${ }^{26}$ It became, as Prosser noted, "not the middle but the minimum common skill which is to be looked to." 27

This principle of deference to physician judgment migrated to contract law as well. Private health insurance did not become widespread in the United States

24. Of course, procedural due process is required only in settings where the government is an actor or in public institutions such as courts. Decisions by private sector physicians or insurers are not generally considered to be state action. E.g., Am. Mfrs. Mut. Ins. Co. v. Sullivan, 526 U.S. 40 (1999); Blum v. Yaretsky, 457 U.S. 991 (1982). In addition, however, there is a broader cultural concept of due process.

25. Kenneth Allen de Ville, Medical Malpractice in Nineteenth Century america: ORIGINS AND LEGACY 157-66 (1990); Charles Markowitz, Medical Standard of Care Jurisprudence as Evolutionary Process: Implications Under Managed Care, 2 Yale J. Health PoL'Y L. \& ETHICS 59 (2001); Theodore Silver, One Hundred Years of Harmful Error: The Historical Jurisprudence of Medical Malpractice, 1992 WIS. L. REV. 1193.

26. Markowitz, supra note 25, at 62-64; Silver, supra note 25, at 1213. Philip Peters argues that "judicial deference to physicians' customs [has been] quietly eroding" in the law of malpractice in the 1980s and 1990s, a trend that he tracks as coinciding with a sharp decrease in the level of public trust for physicians. Philip G. Peters, Jr., The Quiet Demise of Deference to Custom: Malpractice Law at the Millennium, 57 WASH. \& LEE L. REV. 163, 170, 196-97 (2000). Many of the same factors that, according to Peters, diminished trust and created a new trend in malpractice law also fueled the creation of external review systems and drove the system toward a due process paradigm.

27. W. Page Keeton, et al., Prosser and Keeton on the Law of Torts $\S 32$, at 187 (5th ed. 1984). 
until World War II, when its adoption spread through contractual arrangements between insurers and employers, with employees as third-party beneficiaries. ${ }^{28}$ Prior to the widespread use of managed care organizations as insurers, physicians provided the treatment which they in their sole judgment considered to be medically necessary, and insurers almost invariably reimbursed on that basis. ${ }^{29}$ Doctors and other providers thus implicitly determined the scope of the terms of insurance contracts, which were and still are almost universally written to cover care which is medically necessary. ${ }^{30}$

Several factors resulted in the anomaly of market players, whose economic interests lay in minimizing medical expenses, acceding to determinations of medical necessity by care providers who would profit from larger expenditures. One was the relative modesty of health care costs, as a portion of the economy and as compared to the much higher levels of expenditure today. ${ }^{31}$ Another was the control by physicians and hospitals of Blue Shield and Blue Cross, respectively, the two entities which created most of the early group health plans. $^{32}$ Thus provider-dominated institutions reviewed determinations of medical necessity made by providers.

Congress reinforced provider control in 1965 when it adopted customary professional charges as the basis for Medicare reimbursement, a system that dwarfed in size any individual insurance company. ${ }^{33}$ Private reimbursement entities found it economically efficient to adopt the Medicare standard.

28. Paul A. Starr, The Social Transformation of American Medicine 200-06 (1982); Hyman \& Hall, supra note 7 , at 25-26.

29. E. HaAvi Morreim, Holding Health Care Accountable: Law and the New Medical MarketPlaCe 45-46 (2001); Marcia Angell, The Doctor as Double Agent, 3 Kennedy Institute OF ETHICS J. 279, 281 (1993) (noting that "the third parties [payors] happily paid the charges, with few questions asked"); Mark A. Hall \& Gerard F. Anderson, Health Insurers' Assessment of Medical Necessity, 140 U. PA. L. REv. 1637, 1644-45 (1992).

30. Sara Rosenbaum et al., Who Should Determine When Health Care Is Medically Necessary?, 340 NEw ENG. J. MED. 229, 230 (1999).

31. Health care expenses accounted for less than 6\% of the gross national product in 1965. Bradford H. Gray, The Profit Motive and Patient Care: The Changing Accountability of DOCTORS AND HOSPITALS 246 (1991). The proportion rose to $9.1 \%$ in 1980 and then to $12.1 \%$ in 1990. Rand Rosenblatt et al., Law and the American Health Care System 16 (1997). Recent figures project an increase in the health share of gross domestic product from $15.3 \%$ in 2003 to $18.7 \%$ in 2014. Stephen Heffler et al., Health Spending Projections for 2004-2014, HEALTH AFF., Feb. 23, 2005, at W5-74, http://content.healthaffairs.org/webexclusives/ index.dtl?year $=2005$.

32. Starr, supra note 28, at 306-09; Sylvia A. Law, The Health Law Project of the University of PenNSylvania, Blue Cross: What Went Wrong 7-11, 19-20, $26-27$ (1974).

33. Judith M. Feder, Medicare: The Politics of Federal hospital insurance 2-3, 37 (1977); LAW, supra note 32, at 59-65, 117; STARR, supra note 28 , at 375, 385. 
Physicians fought early efforts to reign in costs. ${ }^{34}$ Even as both public and private payors shifted farther and farther away from a charges-based or fee-for-service system, ${ }^{35}$ the foundational fee-for-service structure limited the possibilities for any significant change.

In payment disputes and in private law matters such as malpractice suits, courts asked whether the doctor's acts met the professional custom test, or whether the insurer had properly applied statutory or contract standards of medical necessity. In tort, the collective norm of physicians created the standard by which malpractice decisions were rendered. In contract, public and private insurers acceded to individual physicians' decisions as binding, creating a custom of deference by the market to provider decision-making.

An even more powerful form of deference to physician judgment became a feature of constitutional law as well. When medical decision-making occurs in a public institution or as part of a governmental benefits (as distinct from insurance) program, a doctor's decision can become the decision of the state. The state action required for the procedural due process clause to apply may come from the fact that the decision-making process is a statutory creation ${ }^{36}$ or from the fact that the doctor is an employee of the state. ${ }^{37}$ In such cases the law has extended direct deference, framing the question as whether a qualified physician made this decision within professional bounds. ${ }^{38}$

In procedural due process cases, the core question focuses on certain indicia of decision-making: notice, opportunity to contest, an impartial decision-maker, a fully-articulated rationale, the opportunity to appeal, and other desiderata of

34. For example, in 1975 the American Medical Association (AMA) blocked implementation of hospital utilization review committees for Medicare and Medicaid enrollees. Am. Med. Ass'n v. Weinberger, 395 F. Supp. 515 (N.D. Ill. 1975). The AMA asserted the constitutional right of physicians to practice medicine by exercising their best medical judgment, $i d$. at 520 , and also asserted that the regulations at issue violated a statutory provision which prohibited government officials from "exercis[ing] any supervision or control over the practice of medicine or the manner in which medical services are provided," $i d$. at 524 (quoting 42 U.S.C. $\S 1395$ ).

35. The Medicare program began the professional standards review organization (PSRO) system in the early 1970s. Although physician-controlled, PSROs developed criteria for assessing appropriateness of care, thus ending automatic acceptance of customary charges set by hospitals. Congress replaced PSROs with peer review organizations (PROs) in 1984, in part to encourage systems with greater independence from hospitals. GRAY, supra note 31, at 246-48; FEDER, supra note 33, at 117-35; LAw, supra note 32 , at 130-31.

36. See, e.g., Mathews v. Eldridge, 424 U.S. 319 (1976); infra text accompanying notes 52-59.

37. West v. Adkins, 487 U.S. 42 (1988) (holding that decisions by prison doctor are state action).

38. See, e.g., Youngberg v. Romeo, 457 U.S. 307, 321 (1982). 
fairness. ${ }^{39}$ Although a robust adherence to the principles of procedural due process may be necessary to keep our constitutional democracy honest, the concept of procedural due process itself is thin. Its protection attaches based on an uncertain trigger: when the individual faces "jeopardy of serious loss." Moreover, the Supreme Court has decided that only three component rights of procedural due process are essential: adequate notice, ${ }^{41}$ a hearing at a meaningful time, ${ }^{42}$ and a hearing before an impartial decision-maker. ${ }^{43}$ Procedural due process does not necessarily include, for example, the right to a written decision ${ }^{44}$ or to an appeal. ${ }^{45}$ The Court has made clear that the contours of procedural due process should not be "technical [or] ... unrelated to time, place and circumstances;", but rather "flexible[,] and [include] . . . such procedural protections as the particular situation demands." ${ }^{, 47}$ Yet, however porous, the components of procedural due process provide the fundamental metric by which we assess adjudicatory systems.

Many aspects of health law process, however, became an exception to the normal operations of procedural due process requirements. In the decision that set the existing standard for procedural due process analysis, medical authority functioned as a substitute for procedural protections. In Mathews v. Eldridge, ${ }^{48}$ a case involving the termination of disability benefits under the Supplemental Security Income (SSI) program, the Supreme Court used a radically different approach to assessing the need for prior evidentiary hearings than it had reached six years earlier in the seminal procedural due process case of Goldberg $v$.

39. Erwin Chemerinsky, Constitutional Law: Principles and Policies 557-58 (2d ed. 2002).

40. Joint Anti-Fascist Refugee Comm. v. McGrath, 341 U.S. 123, 171 (1951) (Frankfurter, J., concurring).

41. Mullane v. Cent. Hanover Bank \& Trust Co., 339 U.S. 306 (1950).

42. Fuentes v. Shevin, 407 U.S. 67 (1972); Goldberg v. Kelly, 397 U.S. 254 (1970).

43. United States v. James Daniel Good Real Prop., 510 U.S. 43, 55 (1993); Schweiker v. McClure, 456 U.S. 188, 195 (1982). Several commentators have suggested that an independent decision-maker should be the most important single prerequisite of a constitutionally acceptable proceeding. Henry J. Friendly, "Some Kind of Hearing," 123 U. PA. L. REv. 1267, 1279 (1975); Martin H. Redish \& Lawrence C. Marshall, Adjudicatony Independence and the Values of Procedural Due Process, 95 Y ALE L.J. 455, 475-76 (1986).

44. John Leubsdorf, Constitutional Civil Procedure, 63 Tex. L. Rev. 579 (1984); Martha 1. Morgan, The Constitutional Right To Know Why, 17 HARV. C.R.-C.L. L. REv. 297 (1982).

45. M.L.B. v. S.L.J., 519 U.S. 102 (1996); Lindsey v. Normet, 405 U.S. 56, 77 (1972); Leubsdorf, supra note 44, at 628; Kenneth E. Scott, Two Models of Due Process, 27 STAN. L. REV. 937, 945 (1975).

46. Mathews v. Eldridge, 424 U.S. 319, 334 (1976).

47. Id.

48. 424 U.S. 319 (1976). 
Kelly. ${ }^{49}$ In Goldberg the Court ruled that the Constitution required evidentiary hearings prior to a cut-off of welfare benefits, and that the subsequent hearings provided for by the relevant statute, the Aid to Families with Dependent Children (AFDC), were insufficient. ${ }^{50}$ By contrast, in Eldridge, the Court found that no evidentiary hearing was required prior to the termination of disability benefits under the SSI program. ${ }^{51}$

The defining difference for the Court between the two cases was that the SSI statute required a medical assessment as to whether an individual's disability made that individual unable to engage in any substantial gainful activity. ${ }^{52}$ Such an assessment, reasoned the Court, "is a more sharply focused and easily documented decision than the typical determination of welfare entitlement.

The Court then adopted, in Eldridge, what remains its test for what process is due: a balancing of factors that embodies a rough cost-benefit assessment of whatever enhanced procedure is being sought. The Court held that the assessment would depend on a comparison of the nature of the personal interest at risk and its importance to the individual, the cost to the government of the additional procedural protections being sought, and the risk of an erroneous decision balanced against the likelihood that the additional protections would produce a more accurate outcome..$^{54}$ In the three-part test adopted in Eldridge, the question of how much greater accuracy in outcome a hearing, for example, would produce works as the tie-breaker between the competing interests of the two parties. ${ }^{55}$

The Court thus allowed the final decision, in cases where evidence was conflicting, to turn on physicians' reports, with medical judgment serving as the

49. 397 U.S. 254 (1970).

50. Id. at $264,266$.

51. 424 U.S. at 340 . The SSI program provides income benefits to an individual who, because of his or her disability, is unable to engage in any substantial gainful employment. Such individual must also meet certain income limitations. 42 U.S.C. $\$ 423$ (2000).

52. The Court also noted that the earlier case had involved cash payments to enable indigents to secure necessities such as food and shelter. This distinction is unpersuasive for three reasons. First, it essentially limited Goldberg to its facts, when the Court's language in Goldberg had been sweeping. Second, because SSI is an income replacement program, it differs little in function from the AFDC benefits at issue in Goldberg. Third, the Court had already explicitly declined to limit the Goldberg principle to cases involving the necessities of life. Fuentes v. Shevin, 407 U.S. 67,88 (1972).

53. 424 U.S. at 343.

54. Id. at 334-35.

55. Jerry L. Mashaw, The Supreme Court's Due Process Calculus for Administrative Adjudication in Mathews v. Eldridge: Three Factors in Search of a Theory of Value, 44 U. CHI. L. REV. 28, 29 (1976). 
tie-breaking factor. ${ }^{56}$ Justice Brennan's dissent in Eldridge ${ }^{57}$ referred to his dissenting opinion in Richardson $v$. Wright, in which he rejected the use of medical authority as a substitute for a pre-termination hearing: "I see no reason to suppose ... that the 'credibility and veracity' of doctors . . . can never be in issue." $" 58$

In Eldridge the Court asserted it was drawing on medical authority as a source of neutral evidence in determining whether an individual's physical condition met the statutory criteria for disability. In reality, however, the Court was invoking deference to physician judgment as an alternative process paradigm. The Court imported deference to medical authority from tort law, and then deployed it as the primary rationale for its conclusion that the additional protection of a prior evidentiary hearing would result in no greater likelihood of an accurate determination. Medical authority thus helped mark the boundaries of procedural due process. $^{59}$

56. 424 U.S. at 344. To some extent, the Court's reliance on medical judgment fudged the issue, since the dispute turned on a disagreement between doctors, with the enrollee's physician contesting the assessment of the government's medical expert. Thus, it was also a contest over which doctor, or whose doctors, would be believed. The profession itself had already recognized the ethical problems implicit in physicians working for government and private sector entities in a capacity in which the goal was to curb expenses. Robert M. Veatch, Ethical Dilemmas of ForProfit Enterprise in Health Care, in The New Health Care for Profit: Doctors and Hospitals in A COMPetitive EnVIRONMENT 125, 131, 143-44 (Bradford H. Gray ed., 1983). A 1969 American Medical Association Judicial Council opinion called such arrangements "absolutely destructive of that personal responsibility and relationship which is essential to the best interest of the patient." $I d$. at 131 .

57. 424 U.S. at $349-50$.

58. Richardson v. Wright, 405 U.S. 208, 219 (1972). The Wright case had raised the same issue as to pre-termination hearings as in Eldridge; the Court had remanded it for consideration of what were then pending new regulations. Eldridge eventually came before the Court challenging the revised regulations.

59. Even stronger strains of deference emerged in cases involving treatment decisions by physicians employed by state institutions. In Parham v. J.R., 442 U.S. 584 (1979), the Supreme Court rejected the need for a judicial hearing in an involuntary civil commitment proceeding for a minor, citing Eldridge and the principle of medical deference. Id. at 607-09. In Youngberg $v$. Romeo, 457 U.S. 307 (1982), the Court adopted the professional judgment rule, directing courts to defer to physicians' decisions regarding treatment of institutionalized persons unless a doctor's decision was "such a substantial departure from accepted professional . . . standards as to demonstrate that the person responsible actually did not base the decision on such a judgment." $I d$. at 323 . The due process right asserted by institutionalized persons has both a substantive component - for example, the right to be free of bodily restraints--and a procedural component, i.e., the right to a set of minimally necessary procedural steps for the review of whether a substantive right has been violated. Washington v. Harper, 494 U.S. 210, 220 (1990). Courts 


\section{B. The Hidden Assumptions of Deference}

In Eldridge the persuasive power of the decision hinges on trust in the proxy for accuracy that the Court has invoked: medical authority. The Court softened the cold edge of a legal standard based on a cost-benefit calculation by relying on perhaps the last bastion of benign paternalism. Yet when one examines closely the basis for expanding deference from a standard of review for past acts into a proxy for fair process in making externally binding, prospective decisions, the rationale does not work.

The assumption that an additional evidentiary hearing would not improve protection against error in a cost-effective way works only if courts accept that medical decisions come with their own intrinsic protections against error, and against exactly the types of error-those involving credibility, veracity and bias - that evidentiary hearings and cross-examination are designed to prevent. But is this really true of medical practice? Medical decisions are certainly subject to the risks common to all decision-making processes against which due process criteria ordinarily provide a shield. Under the basic principle that the degree to which procedural refinements attach is contextual, related to the nature of the decision and its consequences, at least some medical decisions would seem to call for a fuller, rather than a more truncated, set of procedural guarantees. Such decisions have a highly consequential risk of error. Decisions as to the course or scope of treatment (including what is medically necessary) are often the products of informed judgment, not a simple application of scientific fact, and are highly indeterminate. ${ }^{60}$ Most medical decisions are made by individuals, rather than by formal institutional processes. And some of those decisions are enforceable by the state. All of these characteristics signal a need for heightened sensitivity to the integrity of the process.

Consider the following four possible risks applicable to medical decisions:

(1) A physician may make an arbitrary decision, i.e., a decision which

conflated the two, however, under the rubric of the professional judgment standard: "[I]f a plaintiff's substantive due process rights were not violated (because professional judgment was exercised), any procedural due process requirements (which require essentially the same exercise of professional judgment) would undoubtedly have been fulfilled as well." Wells v. Franzen, 777 F.2d 1258, 1261 n.2 (7th Cir. 1985), quoted in Susan Stefan, Leaving Civil Rights to the "Experts": From Deference to Abdication Under the Professional Judgment Standard, 102 YALE L.J. 639, 651-54, 680 (1992).

60. Carl E. Schneider, The Practice of Autonomy: Patients, Doctors, and Medical DeCisions 130-34 (1998); M. Gregg Bloche, The Invention of Health Law, 91 CAL. L. REV. 247, 266-70 (2003); Jay Alexander Gold, Wiser Than the Laws?: The Legal Accountability of the Medical Profession, 7 AM. J.L. \& MED. 145, 165-71 (1981); Harold S. Luft, Economic Incentives and Clinical Decisions, in The New Health CARE for Profit, supra note 56, at 103, 105-06. 
is the product of an abuse of appropriate process norms. A physician's refusal to consider relevant evidence would be an example of such arbitrariness. The outcomes of such decisions might be good or bad, right or wrong, in both utilitarian and normative terms, but they would be nonetheless tainted by the lack of regularity and predictability.

(2) A physician may make a biased decision, i.e., a decision reflecting a pattern of unfairness, which disparages the interests of certain persons or classes of persons. Physicians may adhere to process rules in some cases, but not in others, leading to differential outcomes that are unfair insofar as similar arguments, situations, or conditions are treated differently in different cases.

(3) A physician may make a corrupted decision, i.e., a decision driven by the self-interest of the decision-maker. Decisions tainted by conflicts of interest may affect all classes or groups of patients, and may seem arbitrary, but they are in fact motivated by a specific, clear purpose. The purpose which drives the process, however, is illegitimate.

(4) Finally, a physician may make a careless decision, i.e., a decision based on hasty, ill-considered, or unsupported beliefs. Insufficiencies in the decision-maker's training, self-discipline, or commitment to improvement can produce decisions that are more negligent than arbitrary, evenly applied and of no personal benefit to the decision-maker.

Protection against all four such risks is necessary for a decision-making process to have integrity as a process. ${ }^{61}$ Deference to medical authority makes sense only if it plausibly provides protection against such risks. At least for the first three risks, ${ }^{62}$ such protection requires more than a body of expert scientific

61. In an article reviewing the literature on the role of trust in medical relationships, Mark Hall and colleagues conceptualize multiple dimensions of trust in a model that closely approximates my framework for the categories of risk to process integrity. They identify the dimensions of trust as: fidelity ("pursuing a patient's best interests and not taking advantage of his or her vulnerability"); competence (avoiding mistakes and maximizing the optimal outcome); honesty (including avoidance of deception by silence); confidentiality ("proper use of sensitive or private information"); and global trust (the holistic aspect of trust, reflecting the interconnection of the various dimensions). Mark A. Hall et al., Trust in Physicians and Medical Institutions: What Is It, Can It Be Measured, and Does It Matter?, 79 Milbank Q. 613, 620-24 (2001). The authors conclude that professional norms and culture serve the function of preserving trust. Id. at 633 .

62. As to the fourth concern, hospital-based peer review committees (now called quality improvement committees) provide the chief policing mechanism within medicine. TROYEN A. Brennan \& Donald M. Berwick, New Rules: Regulation, Markets, and the Quality of 
knowledge. What it requires is consistent adherence to the fiduciary principle that a physician will place the interests of her patient above all else. Faith in that principle is central to health process exceptionalism.

The basis for requiring that physicians act as fiduciaries is the recognition that information, power, and susceptibility to harm differ between doctor and patient. ${ }^{63}$ Despite high standards within the profession, it is not self-evident that physicians will always properly carry out their fiduciary duties.

The fiduciary principle is broadly conceptualized as an ethical ideal,${ }^{64}$ but much more narrowly enforced as a legal requirement which could be relied on as a substitute for procedural protections in decision-making. As William Sage has noted, whereas corporate law enforces the duty of loyalty by fiduciaries, health law "relegates loyalty to poorly enforced professional disciplinary processes." 65 The fiduciary principle has been most useful in health law for establishing the scope of a physician's duties directly to her patients. As one scholar has noted: "Remarkably, U.S. health law has not yet widely recognized a duty of loyalty, distinct from professional obligations with respect to quality and confidentiality." ${ }^{, 66}$ Even there, while courts and commentators have casually cited it as self-evident, ${ }^{67}$ the power of law has been used to enforce the principle mostly in informed consent cases. ${ }^{68}$

The role of payors offers a critical challenge to the fiduciary relationship between patients and physicians. Payors, whether government or private, have significant economic and political power with which to protect themselves from

AMERICAN HEALTH CARE 178-85 (1996). Ethics committees also address some of these issues, but they too suffer from process deficiencies. See Robin Fretwell Wilson, Hospital Ethics Committees as the Forum of Last Resort: An Idea Whose Time Has Not Come, 76 N.C. L. REV. 353 (1998); Susan M. Wolf, Ethics Committees and Due Process: Nesting Rights in a Community of Caring, 50 MD. L. REv. 798 (1991).

63. Maxwell J. Mehlman, Fiduciary Contracting: Limitations on Bargaining Between Patients and Health Care Providers, 51 U. PITT. L. REV. 365 (1990).

64. See, e.g., Council on Ethical \& Judicial Affairs, Am. Med. Ass'n, Ethical Issues in Managed Care, 273 JAMA 330 (1995) [hereinafter Ethical Issues in Managed Care].

65. Sage, supra note 3, at 610; see also Mark A. Hall, Law, Medicine, and Trust, 55 STAN. L. REV. 463, 503 (2002) (comparing enforcement to a "speakeasy" system).

66. M. Gregg Bloche, Clinical Loyalties and the Social Purposes of Medicine, 281 JAMA 268, 273 (1999).

67. Joseph M. Healey, Jr. \& Kara L. Downey, Controlling Conflicts of Interest in the DoctorPatient Relationship: Lessons from Moore v. Regents of the University of California, 42 MERCER L. REV. 989, 1001-02 (1991).

68. Hall, supra note 65, at 489-90; Marc A. Rodwin, Strains in the Fiduciary Metaphor: Divided Physician Loyalties and Obligations in a Changing Health Care System, 21 AM. J.L. \& MED. 241, 247 (1995). 
decision-making processes that they consider to be unfair or biased against their interests, more so than patients. Moreover, the potential harm of diminished health from inadequate process protections that patients face is less remediable than the risk of lost revenue to payors. Until the 1990s, however, insured patients were largely protected from those consequences by the same flaws in the medical marketplace that drove up costs: the incentives under fee for service to provide every legitimate treatment to every patient. It was that aberration, more than the fiduciary principle itself and certainly more than any enforcement of the fiduciary principle, that mitigated the need for process protections on behalf of patients seeking reimbursement of medical expenses.

In the payment realm the advent of managed care, driven by cost containment imperatives, killed deference, thus ending the economically strange regime of fee-for-service systems. Massive, spiraling health care costs could not be attacked without a rollback of the degree of physician authority that had characterized fee-for-service insurance payment systems. Managed care struck at the heart of unnecessary costs by the combination of a capitated pricing and payment system, ${ }^{69}$ financial incentives to doctors and other providers to conserve care, and financial penalties to patients who had to pay "extra" in some form to go outside the system. ${ }^{70}$ Managed care companies continue to use withholds, or the sequestration of some part of overall compensation owed to a physician until the company performs an accounting of whether amounts will be deducted because that doctor over-utilized expensive treatments or referrals. Or, they may achieve essentially the same goal by paying bonuses to doctors who meet utilization goals. Even without formal corporate policies of either kind, pressure has been building on physicians since the costs explosion of the $1980 \mathrm{~s}$ to engage in "bedside rationing."

Beginning in the 1980 s health policy analysts recognized the growing potential for financial conflicts of interest between doctor and patient, since doctors operating under the fee-for-service system could multiply their income by ordering unnecessary, if usually not harmful, tests and procedures. ${ }^{72}$ The first

69. Under a capitation system, providers receive a fixed monthly or yearly amount for each patient enrolled with that provider.

70. See description of financial incentives in David Orentlicher, Paying Physicians More To Do Less: Financial Incentives to Limit Care, 30 U. RiCH. L. Rev. 155, 158-60 (1996).

71. Bloche \& Jacobson, supra note 12; Einer Elhauge, Allocating Health Care Morally, 82 CAL. L. Rev. 1449, 1457-65 (1994); Mark A. Hall, Rationing Health Care at the Bedside, 69 N.Y.U. L. REV. 693 (1994).

72. Am. Med. Ass'n, Report of the Council on Ethical and Judicial Affairs on CONFLICTS OF INTEREST (1986); GRAY, supra note 31, at 251-55; James S. Todd \& Janet K. Horan, Physician Referral-The AMA View, 262 JAMA 395 (1989). For a longer historical perspective on the conflicts of interest intrinsic to medical care structured as businesses for providing services, see 
judicial decision to focus on financial incentives was Moore v. Regents of the University of California ${ }^{73}$ in which the California Supreme Court ruled that a physician who profited by sale of stem cells from a patient who was unaware that his tissue was being used to harvest those materials could be liable for failure to obtain informed consent. Yet what now seems most significant about Moore is the extent to which it did not generate any further new law. ${ }^{74}$

The transformation to managed care in the $1990 \mathrm{~s}$, in which financial incentives exert pressure for under- rather than over-treatment, exacerbated the risk of tainted decision-making, even producing debates over whether there should be a new version of the professional custom rule, in which physicians undertook fiduciary duties and concomitant responsibilities for the purpose of cost containment. ${ }^{75}$ Researchers found that doctors did not propose treatments which they believed would be medically beneficial because of insurance coverage restrictions. ${ }^{76}$

Despite such pressures on ethical aspirations, courts by and large have not expanded the Moore principle to address problems of physician conduct related to managed care. ${ }^{77}$ The circuits are split on the question of whether to impose a fiduciary obligation under ERISA that would require insurers to notify patients of the financial incentives operating in their plan. ${ }^{78}$ The reality, however, is that

Veatch, supra note 56.

73. 793 P.2d 479 (Cal. 1990).

74. Joan H. Krause, Reconceptualizing Informed Consent in an Era of Health Care Cost Containment, 85 IowA L. REv. 261, 340-41 (1991); Lori Potter, Failure To Disclose HMO Incentives and the Breach of Fiduciary Duty: Is a New Cause of Action Against Physicians the Best Solution?, 34 U.S.F. L. REV. 733, 755 (2000).

75. Angell, supra note 29; Thomas H. Boyd, Cost Containment and the Physician's Duty to the Patient, 39 DePaUl L. Rev. 131, 154-55 (1989); Jerome P. Kassirer, Managing Care-Should We Adopt a New Ethic?, 339 New Eng. J. MeD. 397 (1998); Roger Menendez et al., A New Ethic for Medicine?, 339 NEW ENG. J. MED. 1326 (1998); E. Haavi Morreim, Medicine Meets Resource Limits: Restructuring the Legal Standard of Care, 59 U. PITT. L. REV. 1, 27-35, 64-72 (1997); Edmund D. Pellegrino, Interests, Obligations, and Justice: Some Notes Toward an Ethic of Managed Care, 6 J. CliniCAL ETHICS 312, 314-16 (1995).

76. Sherry Glied \& Sarah E. Little, The Uninsured and the Benefits of Medical Progress, 22 Health Aff. 210 (2003); Matthew K. Wynia et al., Do Physicians Not Offer Useful Services Because of Coverage Restrictions?, 22 HEALTH AFF. 190 (2003) (noting that thirty-one percent of doctors did not discuss useful treatments with patients because of insurance restrictions). Physicians also manipulate insurers' rules in order to secure coverage which otherwise would not be covered. Matthew K. Wynia et al., Physician Manipulation of Reimbursement Rules for Patients, 283 JAMA 1858 (2000).

77. Peter D. Jacobson, Strangers in the Night: Law and Medicine in the Managed Care ERA 222-49 (2002); Rodwin, supra note 68.

78. See, e.g., Horvath v. Keystone Health Plan E., Inc., 333 F.3d 450, 460-62 (3d Cir. 2003) 
financial incentives may create conflicts even for treating physicians (and not just for administrators of $\mathrm{MCOs}$ ). ${ }^{79}$ One commentator has suggested that physicians have gone from being patients' agents, to being double agents, to now being free agents. ${ }^{80}$ Haavi Morreim observed that the acid test of whether a fiduciary relationship is operating properly is whether the more powerful party is engaged in conduct which she would feel uncomfortable revealing to the other party. ${ }^{81}$ In practice, however, fiduciary relationships are seldom tested. Doctors have resisted starting down the road of financial disclosures to patients, ${ }^{82}$ expressing concern that such disclosure would undercut trust, ${ }^{83}$ and only a handful of courts have compelled such disclosure. ${ }^{84}$

(holding that an HMO had no duty under ERISA to disclose financial incentives plan to patient); Ehlmann v. Kaiser Found. Health Plan of Tex., 198 F.3d 552 (5th Cir. 2000) (same); Shea v. Esensten, 107 F.3d 625, 629 (8th Cir. 1997) (finding that plaintiff stated a viable claim that ERISA imposed such a duty); 42 C.F.R. 422.210(b) (2004) (disclosure of financial incentives required for Medicare plans); see also Timothy S. Hall, Bargaining with Hippocrates: Managed Care and the Doctor-Patient Relationship, 54 S.C. L. REv. 689, $716-17$ (2003); Tracy E. Miller \& William M. Sage, Disclosing Financial Incentives, 281 JAMA 1424, 1425-26 (1999). The AMA has adopted the distinction between duties of the MCO and duties of the physicians. The House of Delegates voted in 1997 to place "primary responsibility for disclosure on health plans," with physicians having "some obligation" to describe incentives if the plan does not. Id. at 1425 . In 1995 its Council on ethical issues recommended a requirement of disclosure only by the plan. Ethical Issues in Managed Care, supra note 64, at 335.

79. Sage, supra note 3, at 609.

80. Hoangmai H. Pham et al., Financial Pressures Spur Physician Entrepreneurialism, 23 HEALTh AFF. 70,79 (2004).

81. E. Haavi Morreim, Economic Disclosure and Economic Advocacy: New Duties in the Medical Standard of Care, 12 J. LEGAL MED. 275, 314 (1991).

82. According to a report by two health policy researchers, "The AMA's code of ethics requires that physicians discuss with new patients how they are paid by the plan. ... In the absence of any effective enforcement mechanism, it seems unlikely that many physicians actually convey this information." David Mechanic \& Mark Schlesinger, The Impact of Managed Care on Patients ' Trust in Medical Care and Their Physicians, 275 JAMA 1693, 1694 (1996).

83. Bloche, supra note 66, at 273; Miller \& Sage, supra note 78.

84. See Neade v. Portes, 710 N.E.2d 418, 425-27 (IIl. App. Ct. 1999), aff'd in part and rev'd in part, 739 N.E.2d 496 (III. 2000) (applying fiduciary requirement to physicians). Minnesota requires physician disclosure by statute. MINN. STAT. ANN. $\$ 62 \mathrm{~J} .72(1)$ (West 2005). Courts rejected claims based on fiduciary principles in D.A.B. v. Brown, 570 N.W.2d 168, 172 (Minn. Ct. App. 1997), a decision which may have triggered the legislature to enact the previously-cited statute, and Spoor $v$. Serota, 852 P.2d 1292, 1294-95 (Colo. Ct. App. 1992). Cf. Batas v. Prudential Ins. Co., 724 N.Y.S.2d 3, 13 (App. Div. 2001) (holding that no fiduciary relationship exists between a health insurer and an insured party). For arguments that courts should use fiduciary principles to analyze managed-care-related conflicts of interests, see Peter D. Jacobson \& Michael T. Cahill, Applying Fiduciary Responsibilities in the Managed Care Context, 26 AM. J.L. \& MED. 155, 165-66 (2000). 
A combination of the status and culture of the medical profession, together with irrational market forces, resulted in deference by payors lasting as long as it did, but the economic irrationality of the old system eventually broke down. Large institutional payors abandoned the custom of deference to physicians, which in effect pulled the financial rug out from under the fiduciary principle. ${ }^{85}$ Physician adherence to a fiduciary responsibility has now become far more genuinely altruistic than it formerly was.

In cases at the intersection of medicine and due process, courts used medical authority as a substitute for what otherwise could have been a fuller examination of process questions. The tendency of courts in the procedural due process cases to over-read the fiduciary principle corrupted the process component of health law. With managed care the central process question now is not the extent to which physicians' decisions are binding on third parties, but the extent to which medical caregivers are bound by third parties.

\section{From Deference to Due Process}

\section{Truth Gives Way to Justice}

The use of deference in tort and contract law functioned as an example of what procedure scholars John Thibaut and Laurens Walker called "truth-seeking" processes: processes designed to resolve a cognitive conflict, to find an answer that would be recognized by all parties as "correct" according to mutually accepted standards. ${ }^{86}$ Writing in the late $1970 \mathrm{~s}$, when other scholars were analyzing and dissecting the terms of the procedural due process debates epitomized by such cases as Mathews v. Eldridge ${ }^{87}$ Thibaut and Walker drew on social psychology research for empirical evidence as to which kinds of procedural devices would most enhance the quality of conflict resolution. One of their threshold conclusions was that conflicts could be divided into cognitive disputes, for which a right answer existed, and distributive disputes, which centered on fairness.

In the traditional cultural view of medicine, physicians have been seen as truth-seekers. Dan Fox has described a medical culture in which authority is asserted "from the top of a hierarchy in which power is derived from knowledge. . . . A principal goal of medical education is to inculcate lifelong

85. John V. Jacobi, Patients at a Loss: Protecting Health Care Consumers Through Data Driven Quality Assurance, 45 U. KAN. L. REv. 705, 721 (1997) ("That game has been lost.").

86. John Thibaut \& Laurens Walker, A Theory of Procedure, 66 CAL. L. REV. 541, 543-44 (1978).

87. See supra text accompanying notes $52-59$. 
habits of deference to superior knowledge and experience." ${ }^{88}$ For truth-seeking or cognitive disputes, Thibaut and Walker asserted that a single autocratic decisionmaker would be the best mechanism for resolving the conflict. ${ }^{89}$ They reasoned that a disinterested third party with control over both process and outcome could best ascertain true facts, better than one constrained to respond to adversarial presentations. ${ }^{90}$ The professional custom standard and the broad practice of judicial deference to medical authority fit within this model, as indicated by the Supreme Court's characterizations of doctors in cases like Eldridge.

Thibaut and Walker's alternative model for process was "justice-seeking," by which they meant a process needed to resolve conflicts of interest, in which answering factual questions would serve only as a means to the end goal of the fairest division of resources. ${ }^{61}$ For this purpose, Thibaut and Walker asserted that it was important to promote the participation of the disputants, to allow them to present their cases as best they could, primarily because the legitimacy of the system as a whole would turn on society's perception of its legitimacy. ${ }^{92}$ Subsequent research has found that for participants in a dispute over justice or distribution, having meaningful control over the process for resolution of the conflict, for example by presenting evidence, is critical to perceptions of fairness and legitimacy. ${ }^{93}$ However, such control is not a significant factor in perceptions of fairness in conflicts over what is perceived as truth.

One way to understand the backlash of discontent against managed care is as a response to the rupturing of the cultural norm of belief in medical authority and to the conversion of a cognitive dispute into a resource dispute without the consent of those whose disputes were to be adjudicated. As a result, health process is now in transition from the truth-seeking to the justice-seeking model. With the widespread enactment of external review systems for appealing $\mathrm{MCO}$ denials of care, the pendulum has swung, so that due process-style guarantees have migrated to medical decision-making, providing insulation from what patients suspect are unreliable medical assessments. External reviews systems are the primary form of the due process model being brought into medical decisionmaking.

The transition is apparent in the rhetoric of managed care debates. The

88. Daniel M. Fox, Physicians Versus Lawyers: A Conflict of Cultures, in AIDS AND THE LAW: A GUIDE FOR the PUBl.IC 210, 213 (Harlon L. Dalton et al. eds., 1987); see also Luft, supra note 60, at 105 (describing physician as "seeker of truth").

89. Thibaut \& Walker, supra note 86 , at 544.

90. Id. at $547-48$.

91. Id. at $541-42$.

92. Id. at 551 .

93. Tom R. Týler et al., Social Justice in a Diverse Society 92 (1997). 
rhetoric used by advocates for external review systems did invoke the cultural power of medical authority and patient trust. ${ }^{94}$ But although the older trope of deference to medical authority has not been completely superseded, the source of protection for patients has definitively shifted to procedural protections. ${ }^{95}$ Where health law was once a process zone largely divorced from procedural due process norms, it has now become a prime location for contemporary procedural due process concerns to blossom.

In a trio of decisions the Supreme Court has affirmed the transition from deference to due process in health process law. ${ }^{96}$ In the first it revealed its own loss of allegiance to the traditional approach to deference evident in Eldridge. ${ }^{97}$ In the second and third it ruled that state action did not attach to these decisions, but accepted that the actions of privately-run external review systems constitute state action. ${ }^{98}$

\section{Pegram v. Herdrich}

The Supreme Court's decision in Pegram v. Herdrich ${ }^{99}$ illustrates that the contemporary image of a physician is considerably less idealized than it once was. There the plaintiff asserted that she had received substandard care because of an eight-day delay in receiving an ultrasound test so that it could be done by a clinic which was affiliated with the HMO with which her employer had contracted for medical services. She attributed her resulting harm to the fact that

94. See, e.g., the comments of Senator Edward Kennedy (D-Mass.) in support of a federal Patients Bill of Rights, including an external review provision: "My final point is the underlying commitment of this legislation to make sure that doctors are going to make the decisions. Trained medical personnel and families are going to make these judgments and decisions." 147 CONG. REC. S6905 (daily ed. June 26, 2001).

95. See, e.g., U.S. Gen. ACCOUnting Office, HMO Complaints and Appeals: Most Key Procedures In Place, but Others Valued by Consumers Largely absent (1998) [hereinafter gao Report]; Sharon Wilcox, Consumer Protection in Private Health Insurance: The Role of CONSUmer Complaints (2000); OfFice of INSPeCtoR Gen., DeP'T OF Health AND Human Servs., Pub. No. OEI-07-94-00281, Medicare HMO APPeal and Grievance Processes: Beneficiaries' Understanding (1996); OfFICE of INSPECtor Gen., DeP'T OF HEalth \& Human Servs., Pub. No. OEI-95-00430, Beneficiary Perspectives of Medicare Risk HMOS (1998); Karen Pollitz et al., The Henry J. Kaiser Fam. Found., Assessing State External Review Programs and the Effects of Pending Federal Patients' Rights Legislation, at v (2002) ("External review is a formal process for resolving disputes between health plans and consumers.").

96. Pegram v. Herdrich, 530 U.S. 211 (2000); Grijalva v. Sullivan, 526 U.S. 1096 (1999); Am. Mfrs. Mut. Ins. Co. v. Sullivan, 526 U.S. 40 (1999).

97. Pegram, 530 U.S. 211.

98. Grijalva, 526 U.S. 1096; Am. Mfrs. Mut. Ins. Co., 526 U.S. 40.

99. 530 U.S. 211 (2000). 
the physician who had examined her was a part owner of the HMO.

On the question presented the Court rejected her argument that the HMO had undertaken fiduciary obligations pursuant to ERISA's provisions governing plan administrators. Additionally, it found her experience to be less than shocking. "Although it is true that the relationship between sparing medical treatment and physician reward is not a subtle one under the [defendant's] scheme, no HMO organization [sic] could survive without some incentive connecting physician reward with treatment rationing." 100

Nor did the Court nostalgically invoke medical authority in older delivery structures as unproblematic:

[I]n an HMO structure, a physician's financial interest lies in providing less care, not more. The check on this influence ... is the professional obligation to provide covered services with a reasonable degree of skill and judgment in the patient's interest. . . The adequacy of professional obligation to counter financial self-interest has been challenged no matter what the form of medical organization. HMOs became popular because fee-for-service physicians were thought to be providing unnecessary or useless services .... ${ }^{01}$

Instead, the Court adopted an explicitly market-centered conceptualization of the physician's role, which is an implicit foundation for the understanding that mechanisms beyond deference would be needed for patient protection.

\section{Grijalva v. Shalala and American Manufacturers Mutual Insurance Co. v. Sullivan}

Standards for medical decision-making based explicitly on due process principles provide a shield against inadequacies in the "professional obligation to counter financial self-interest." ${ }^{102}$ The most frequent incorporation of those standards has occurred in the law regulating public systems of health care delivery, especially Medicare. ${ }^{103}$ In a series of court decisions ${ }^{104}$ alternating with

100. Id. at 220

101. Id. at $219-20$.

102. Id. at 220 .

103. Bill Sage points out that Medicare has provided a vector for the introduction of process norms in medicine: "Before Medicare, the medical profession frequently viewed fair process as whatever physicians said it was and sometimes trampled procedural rights in order to achieve desirable substantive results. After Medicare, physicians increasingly bought into a model of fairness defined instead by law and lawyers..." William M. Sage, The Lawyerization of Medicine, 26 J. HeAlth POL. POL'Y \& L. 1179, 1188 (2001).

104. 946 F. Supp. 747 (D. Ariz. 1996), affd, 152 F.3d 1115 (9th Cir. 1998), vacated and remanded, 526 U.S. 1096 (1999). 
regulatory ${ }^{105}$ and statutory ${ }^{106}$ changes, the law governing appeals of treatment denials by Medicare beneficiaries enrolled in managed care organizations has moved toward much more elaborate due process-based protections.

In Grijalva v. Shalala, first the district court and then the Ninth Circuit Court of Appeals upheld challenges by beneficiaries based on procedural deficiencies. ${ }^{107}$ In so doing, both courts applied the Mathews v. Eldridge balancing test, and distinguished that case based on the finding that the plaintiff Medicare enrollees had a stronger interest in their benefits than Eldridge had in his disability payments. The key factor for why an individual's interest in a recoupable medical expense was entitled to more constitutional weight than a disabled person's monthly cash allowance for living expenses was the structure of managed care. The lower courts found that the Medicare HMO case more closely resembled Goldberg v. Kelly than it did Eldridge, "especially because [plaintiffs] are HMO enrollees," on the ground that "[t]he HMO's initial adverse coverage determination in many cases prevents receipt of medical care," and a reversal "may come too late to rectify the situation." 108 The decision turned not on medical authority or on deference to a treating physician, but on the weight of a claim to needed medical care, to which Medicare beneficiaries had an entitlement. It was the gate-keeping system used by HMOs which effectively created the claim to care.

The Supreme Court's second critical decision for health process law came in a case related to Grijalva. In American Manufacturers Mutual Insurance Co. v. Sullivan, ${ }^{109}$ the Court ruled that private insurers' decisions about whether a treatment met the criteria of medical necessity was not state action. The case involved claimants who sought payment under the workers compensation system for treatments prescribed by their physicians. The employer's insurance company denied coverage on the ground that the treatments in question were not medically necessary, and the state provided for an appeal to a utilization review entity, a private company which provided independent review. The Court ruled that the workers had no statutory entitlement to the benefits unless and until the treating physician's judgment was confirmed on appeal; thus no constitutionally protected deprivation of property had occurred. The insurers' denial was not state action; neither their role in administering the workers compensation program nor

105. Medicare Program: Medicare Appeals of Individual Claims, 42 C.F.R. $\S 405$ (2004); Medicare Program: Improvements to the Medicare+Choice Appeal and Grievance Procedures, 42 C.F.R. $\S 422$ (2004).

106. Balanced Budget Act of $1997 \S 4001$, Pub. L. No. 105-33, 111 Stat. 251.

107. See supra note 104.

108. 946 F. Supp. at 757.

109. 526 U.S. 40 (1999). 
the existence of a state statute authorizing withholding of benefits pending utilization review sufficed to establish that their decisions could be attributed to the state. ${ }^{110}$

The Sullivan ruling was critical because HMOs which delivered health care to Medicare beneficiaries had been subjected to procedural due process scrutiny in Grijalva based on the finding that their treatment decisions constitute state action. ${ }^{11}$ The decisions of the Medicare HMOs, like those of the workers compensation insurers in Sullivan, were subject to review by an outside organization. The Supreme Court vacated and remanded the Ninth Circuit decision in Grijalva in light of its ruling in Sullivan.

However, the Court in Sullivan also accepted the viability of procedural due process challenges to utilization review decisions themselves. The Court explained that "[utilization review organizations (UROs)] are private organizations consisting of health care providers" licensed in the same specialties as the provider whose decision is under review. ${ }^{112}$ Despite the fact that UROs were private entities, the Court declared that "the State's role in creating, supervising, and setting standards for the URO process [do not] differ in any meaningful sense from the creation and administration of any forum for resolving disputes ... [thus] the decision of a URO, like that of any judicial official, may properly be considered state action."13 Sullivan establishes the basis for constitutional challenges to the procedures used by external review organizations. $^{114}$

Although the Court in Sullivan cut at least one of the doctrinal legs out from under Grijalva by reiterating the principle that initial denials by insurers were not state action, it suggested that termination of an ongoing service by a Medicare HMO could be subject to due process protections. ${ }^{15}$ Given the somewhat uncertain implications of the Sullivan decision, the parties in Grijalva settled after the Ninth Circuit decision was remanded. ${ }^{116}$ Despite the shakiness of their claim after Sullivan, plaintiffs were nonetheless able to achieve a significant

110. Id. at $51-58$.

111. Grijalva v. Shalala, 946 F. Supp. 747, $751-53$ (D. Ariz. 1996), aff'd, 152 F.3d 1115 (9th Cir. 1998), vacated and remanded, 526 U.S. 1096 (1999).

112. Am. Mfrs. Mut. Ins. Co., 526 U.S. at 46.

113. Id.at 54.

114. See also Vellios v. IPRO, 765 N.Y.S.2d 222 (N.Y. Sup. Ct. 2003) (allowing a state administrative law challenge to a denial of private insurance coverage by an external review organization).

115. The Court distinguished Goldberg v. Kelly and Mathews v. Eldridge on that basis. Sullivan, 526 U.S. at 61 .

116. Settlement Agreement, Grijalva v. Shalala, No. CIV 93-711 TUC ACM (D. Ariz. Aug. 9, 2000). 
victory. What emerged from the judicial, administrative, and legislative branches was a detailed set of regulations that addressed such issues as the nature and format of the notice of appeal, the requirement that the reason for denial be stated with sufficient clarity to enable the enrollee to argue an appeal, the type size necessary for readability, rules for hearings, review by independent entities, the enrollee's access to HMO documents and other evidence, and both advance notice and a grace period after notice of a denial during which the terminated services would continue. ${ }^{117}$

Grijalva and Sullivan together illustrate that a "due process" discourse has arisen around health care. The assumptions typical of a distributive fairness dispute behind "justice-seeking" models have permeated discussions of external review systems, which are routinely described as centering on patient complaints and appeals. ${ }^{118}$ Even though advocates of external review laws stress their value in avoiding lawsuits, ${ }^{119}$ external review is framed as a mechanism for resolving disputes over entitlement to care much more frequently than they are described as "truth-seeking" disagreements over the medical, scientific accuracy of coverage decisions.

\section{Summation: The Normalization of Health Process}

Managed care has profoundly altered health care financing, delivery, and quality. One of its most significant effects has been on the process component of health law, where the transformation to managed care has undercut the old paradigm of deference to medical judgment. It has done so by revealing or creating (or both) sharp tensions between the interests of physicians and patients. The visibility of these tensions has in turn produced a crisis of confidence in the fiduciary principle and a resultant search for some other mode of protection for patients. That search has led health law to the realm of procedural due process. Due process is the closest thing to trust that the law can construct or the market provide.

The American Medical Association (AMA) accepted the principle that professional and ethical legitimacy attaches to both the treating physician's mandate of fidelity to the individual patient and to an exception from that duty for payors and the physicians in their employ who seek to contain costs. ${ }^{120}$ This AMA ethical statement marks the junction where process rules determine

117. Medicaid Program: Medicaid Managed Care, 42 C.F.R. $\S \S 400,430,431-34,435,438$, 440, 447 (2004).

118. POLLiTZ ET AL., supra note 95, at v; Berman-Sandler, supra note 9, at 237-38.

119. See infra text accompanying notes 259-260.

120. Council on Ethical \& Judicial Affairs, Am. Med. Ass'n, Ethical Issues in Managed Care, 273 JAMA 330, 331 (1995). 
outcome. The apparent simplicity of procedure law hides its importance. When conflicts involving a treatment decision arise between those two legitimate ethical positions, those of treating physicians and those of managed care medical directors, it is the law of procedure that will determine how the conflict is to be resolved.

Moreover, the trend toward due process norms in health law is broader than the issue of identifying which formal adjudicatory procedures should be used. Scholars are shifting to a process values approach, even if not labeling it as such, for other purposes as well. ${ }^{121}$ It is evident in Sara Rosenbaum's proposed standard for assessments of medical necessity; ${ }^{122}$ in Jacobson and Cahill's suggestion that a process based on fiduciary duty principles be entrusted with resolving the tension between expense and quality care; ${ }^{123}$ and in Greaney and Boozang's suggestion of a "mission primacy" standard for reviewing actions of trustees, such that the burden would rest on trustees to demonstrate why charitable mission should not trump resource maximization. ${ }^{124}$ Each of these proposals is grounded in an attempt to instantiate a new set of process criteria.

The old exceptionalism of health process law is dead, along with the fee-forservice model of organization and relatively smaller-sized corporate ownership. Due process values now dominate.

\section{EXTERnAl REVIEW Organizations as AdJUdiCATION SySTEMS}

From 1992 to 1998, the percentage of persons in the private workforce who were enrolled in managed care plans for their health insurance coverage increased by more than fifty percent. ${ }^{125}$ As the public witnessed "the transformation of health care payers from passive poolers of risk to aggressive managers of cost, $" 126$ concern erupted over the incentives for under service, ${ }^{127}$ fed

121. My thanks to Peter Jacobson for pointing out this thread.

122. Rosenbaum et al., supra note 30 .

123. Peter D. Jacobson \& Michael T. Cahill, Applying Fiduciary Responsibilities in the Managed Care Context, 26 AM. J.L. \& MED. 155, 165-66 (2000).

124. Thomas L. Greaney \& Kathleen M. Boozang, Mission. Margin, and Trust in the Nonprofit Health Care Enterprise, 5 YAlE J. HeALth POL'y L. \& Ethics 1, 84 (2005).

125. Laurie McGinley, HMO Fracas Moves to Who Makes Medical Decisions, WaLL ST. J., Feb. 18, 1999, at A24.

126. M. Gregg Bloche, Fidelity and Deceit at the Bedside, 283 JAMA 1881, 1883 (2000).

127. George J. Annas, Patients' Rights in Managed Care-Exit, Voice, and Choice, 337 NEW ENG. J. MED. 210 (1997); R. Adams Dudley \& Harold S. Luft, Managed Care in Transition, 344 NEW ENG. J. MED. 1087 (2001); Rhonda L. Rundle, HMOs Brace Themselves for 'Avalanche' of New Laws: California Bills on Dispute-Resolution Process Could Be Model for U.S., WALL ST. J., Feb. 20, 1998, at B4. 
by horror stories of death or disability resulting from care denied or diagnoses missed when MCOs refused to grant pre-authorization for expensive tests or treatments. ${ }^{128}$ As one commentator has explained: "[M]ost Americans are discomforted by the idea of having their care rationed and, at some level, they understand that managed care is a mechanism for doing so." 129 The creation of review systems for denial of health coverage and care was a core component of the response to the managed care transformation of service delivery. Because external review organizations (EROs) directly addressed the need to have a check on financial incentives for cost-cutting, provisions creating them became a standard component of "patients' bill of rights" legislation. ${ }^{130}$

By the time of the Supreme Court's decision in Moran, external review systems had become the new norm. ${ }^{131}$ Not only were these laws enacted in the great majority of states, but a system of external review for denials of authorizations for treatment was also adopted in Medicare, Medicaid, the military health care system, and the system of health care for federal employees. ${ }^{132}$ The nature of these new entities-are they adjuncts to the medical system or to the legal system? —-became the threshold issue in Moran.

A. The Supreme Court's Analysis of EROs in Rush Prudential HMO, Inc. v. Moran

Debra Moran was diagnosed as suffering from a combination of two painful and debilitating conditions in her right shoulder. ${ }^{133}$ Her health insurance plan

128. Although the allusion to horror stories usually refers to the media, such stories also have surfaced in the text of federal court decisions. See, e.g., Pryzbowski v. U.S. Healthcare, Inc., 245 F.3d 266 (3d Cir. 2001) (MCO delayed in approving back surgery by an out-of-network surgeon, leading to persistent, excruciating pain). For examples of media portrayals, see Michael A. Hiltzik \& David R. Olmos, The Health Care Revolution: Remaking Medicine in California (pts. 1-7), L.A. TimeS, Aug. 27-Aug. 31, 1995; Robert Kuttner, The Lethal Side Effects of Managed Care, BuS. WeEK, Aug. 7, 1995, at 16; Ellyn E. Spragins, Beware Your HMO, NewsweEK, Oct. 23, 1995, at 54.

129. David Mechanic, The Managed Care Backlash: Perceptions and Rhetoric in Health Care Policy and the Potential for Health Care Reform, 79 MILBANK Q. 35, 37 (2001).

130. George J. Annas, A National Bill of Patients' Rights, 338 New ENG. J. Med. 695, 697 (1998); Tracy E. Miller, Center Stage on the Patient Protection Agenda: Grievance and Appeal Rights, 26 J.L. MED. \& ETHICS 89 (1998); Rhonda L. Rundle, External Review of HMO Decisions Becomes Hot Issue, WALL ST. J., Dec. 3, 1998, at B2.

131. Brief for Respondent State of Illinois at *11-12, Rush Prudential HMO, Inc. v. Moran, 536 U.S. 355 (2002) (No. 00-1021), 2001 WL 1548340 (listing states).

132. Mary C. Morgan, Independent Review of Managed Care Decisions, Health L. News, Winter/Spring 2000, at 5, 13-15.

133. The facts in this and the following paragraph are from Rush Prudential HMO, Inc. v. 
required her to go through an in-network provider prior to receiving any specialty care. The in-network primary care physician initially treated her symptoms with physiotherapy, but the symptoms continued. She sought out a surgeon who specialized in treating her particular condition (brachial plexopathy and thoracic outlet syndrome), who recommended a new form of surgery which the specialist had herself originated. After further consultations with in-network physicians, her primary care doctor recommended that Moran receive the newly-developed surgical procedure out-of-network.

Moran's health insurance coverage derived from her husband's group plan at his place of employment. Under that plan Rush Prudential HMO was both the insurer and the provider of care. The plan contract provided that beneficiaries would receive "medically necessary" care. It also provided that Rush Prudential would retain "the broadest possible discretion" to interpret the meaning of "medically necessary" and to determine which services fell within that category. Rush Prudential denied Moran's request for authorization of the out-of-network surgical procedure on the ground that it was not medically necessary. Moran paid the $\$ 94,841$ charge for the surgery herself and then contested the denial.

Moran's health insurance plan was governed by ERISA because it was a private workplace benefits plan. ${ }^{134}$ Because the employer had purchased the plan, rather than self-insure and bear the risk itself, the plan was also subject to state law regulation. ${ }^{135}$ Under the "savings clause" of ERISA, state laws that regulate insurance are exempt from preemption by ERISA $;{ }^{136}$ such state laws directly regulate the insurers within the state that sell plans to employers, and thereby set limits on the terms of plans which are available for purchase by employers. ${ }^{137}$ Therefore, fully-insured ERISA plans are directly regulated by federal law and indirectly regulated by state law.

Under ERISA Moran could have filed suit asserting a denial of benefits due to her under the plan. ${ }^{138}$ However, the standard of review that the court would use to assess whether there had been a wrongful denial of benefits recognized that Rush Prudential was entitled to have exercised discretion in making its

Moran, 536 U.S. 355, 360 (2002).

134. The Employee Retirement Income Security Act (ERISA), 29 U.S.C. $\$ \$ 1001-1461$ (2000) regulates the structure and administration of employee benefits offered by private sector employers. See Phyllis C. Borzi, Distinguishing Between Coverage and Treatment Decisions Under ERISA Health Plans: What's Left of ERISA Preemption?, 49 BUFF. L. REv. 1219, 1222-24 (2001).

135. Self-insured employer-sponsored health plans are deemed not to be insurance for the purpose of state regulatory laws. Thus, even state insurance laws cannot regulate self-insured plans. 29 U.S.C. $§ 1144($ b)(2)(B) (2000); FMC Corp. v. Holliday, 498 U.S. 52, 61 (1990).

136. 29 U.S.C. $\$ 1144(\mathrm{~b})(2)(\mathrm{A})(2000)$.

137. Metro. Life Ins. Co. v. Massachusetts, 471 U.S. 724, 739 (1985).

138. 29 U.S.C. $\$ 1132(a)(2000)$. 
decision. ${ }^{139}$ Only if a court found that there had been an abuse of such discretion would Moran have been entitled under ERISA to recover the costs of her surgery. ${ }^{140}$

Instead, Moran filed suit to enforce an Illinois statute that established an external review system when an HMO denied treatment that had been recommended by the patient's primary care physician on the ground that it was not medically necessary, as was the case here. Under the Illinois system the HMO was compelled to submit the case to an independent physician jointly selected by the patient, her primary care provider, and the HMO. If the independent physician determined that in her judgment the care in question was medically necessary, the HMO was obligated to provide it or, as here, compensate the patient for its cost. A state court ordered Rush Prudential to comply with this statute, and the third-party physician declared that her surgery had been medically necessary. ${ }^{141}$

Rush Prudential nonetheless refused to pay, and defended against Moran's claim for reimbursement on the ground that ERISA preempted the Illinois external review statute. Its primary argument was based on case law which had held that even state laws regulating insurance would be preempted if they altered the enforcement and remedy scheme established by ERISA, reasoning that this "super preemption" was justified by the clear Congressional intent that employers operating group benefits plans should be able to rely on the understanding that they would be liable for only one nationally uniform set of remedies, rather than the differing remedies available under state law. ${ }^{142}$

The federal district court to which Rush Prudential had removed the case concluded that there was preemption and that the ERISA standard, not the results of the external review, governed the question of whether Moran's claim was valid. ${ }^{143}$ The court ruled that it was bound to accord the "broadest possible discretion" to the HMO's decision, and found that there had been no abuse of that discretion. ${ }^{144}$

139. Firestone Tire \& Rubber Co. v. Bruch, 489 U.S. 101, 115 (1989).

140. See, e.g., Jones v. Kodak Med. Assistance Plan, 169 F.3d 1287, 1292 (10th Cir. 1999); Bedrick v. Travelers Ins. Co., 93 F.3d 149, 152 (4th Cir. 1996).

141. Rush Prudential HMO, Inc. v. Moran, 536 U.S. 355, 362 (2002).

142. This interpretation of ERISA originated in Pilot Life Insurance Co. v. Dedeaux, 481 U.S. 41 (1987), where the Court preempted a state-common-law-based suit for bad faith breach of contract. Rush Prudential also made a separate preemption argument that the Illinois statute was not a law regulating insurance, and thus not protected by the savings clause, an argument that the Court rejected. Moran, 536 U.S. at 365-73.

143. Moran v. Rush Prudential HMO, Inc., No. 98 C 442, 1999 WL 417384, at *2-4 (N.D. Ill. June 15,1999$)$

144. Id. at *5. 
The Seventh Circuit reversed, holding that the Illinois statute "simply adds to the [insurance] contract . . . an additional dispute resolving mechanism."145 The court acknowledged that the Fifth Circuit had recently reached the opposite conclusion in a case involving a substantially similar Texas external review law, finding that the Texas law was preempted because it directly conflicted with the ERISA enforcement scheme by "establish[ing] a quasi-administrative procedure for the review of [a decision to deny benefits] and [binding] the ERISA plan to the decision of the independent [reviewer]." "46 Four judges on the Seventh Circuit agreed with the Fifth Circuit, characterizing the Illinois statute as a "law establish[ing] a system of appellate review of benefits decisions" in conflict with the ERISA provisions. ${ }^{147}$

Thus, as the case went to the Supreme Court with an inter-circuit conflict, the question regarding deviation from ERISA's enforcement provisions was framed as whether the Illinois law created an alternative enforcement scheme for adjudicating disputes between patients and HMOs about benefits due under ERISA plans, or whether the law merely mandated one of the terms that insurance contracts sold by HMOs in Illinois were required to include. Most of the parties and amici on both sides found comfort in describing the external review system as quasi-arbitration.

The State of Illinois asserted that its law "effectively requires binding arbitration." 148 Also arguing in support of the law, the United States described the system as a "private, non-judicial arbitration-like mechanism to settle disputes." 49 The AMA used the phrase "independent external review or arbitration." 150 The National Association of Insurance Commissioners called it "an arbitration-like procedure."151 Moran's brief used the phrase "an objective, independent third-party review." 152 These briefs argued that arbitration did not constitute a separate enforcement scheme than ERISA's because the plaintiff was

145. Moran v. Rush Prudential HMO, Inc., 230 F.3d 959, 972 (7th Cir. 2000).

146. Id. at 971 (quoting Corporate Health Ins., Inc. v. Tex. Dep't of Ins., 215 F.3d 526, 539 (5th Cir. 2000), vacated and remanded sub nom. Montemayor v. Corporate Health Ins., 536 U.S. 935 (2002)).

147. Id. at 973 (Posner, J., dissenting from denial of rehearing en banc).

148. Brief for Respondent State of Illinois, supra note 131, at *29.

149. Brief for the United States as Amicus Curiae at *23, Rush Prudential HMO, Inc. v. Moran, 536 U.S. 355 (2002) (No. 00-1021), 2001 WL 1480556.

150. Brief of the American Medical Ass'n et al. as Amici Curiae in support of Respondents at *22, Moran, 536 U.S. 355 (No. 00-1021), 2001 WL 1480546.

151. Brief of the National Ass'n of Insurance Commissioners as Amicus Curiae in support of Respondents at *18, Moran, 536 U.S. 355 (No. 00-1021), 2001 WL 1673395.

152. Brief for Respondent Debra C. Moran at *13, Moran, 536 U.S. 355 (No. 00-1021), 2001 WL 1684554. 
entitled to no greater remedy (e.g., no punitive damages) in arbitration than was provided under ERISA. ${ }^{153}$ All of them, however, framed the question as involving a dispute resolution mechanism.

The opponents of the law also found the arbitration analogy useful. Rush Prudential characterized the Illinois law as a command for "binding de novo arbitration." ${ }^{\text {154 }}$ Such a system provided a different remedy, not a contractual right, it argued. The "only pertinent difference between [this] law and a judicial remedy is that the decision-maker is a physician." ${ }^{\text {"155 }}$ The American Association of Health Plans identified "the distinguishing characteristic" of the law as the fact "that strangers to the plan ... make judgments about how plan assets must be spent that are binding on plan administrators." 156

The four Justices who agreed that the Illinois external review system operated as essentially an arbitration procedure held that this form of dispute resolution was indeed an alternative enforcement mechanism and thus should be preempted. "[A]s a binding decision on the merits of the controversy[,] the [external] review resembles nothing so closely as arbitration." 157 Because the independent physician's determination was conclusive on the ultimate question of whether benefits were due, the dissenting Justices found that the Illinois statute set up a procedure for decision-making that conflicted with the procedure established in ERISA. "There is no question that arbitration constitutes an alternative remedy to litigation." 158

By contrast, the linchpin of the majority's decision was its rejection of the arbitration analogy and, with it, its rejection of the framing of the statute as centering on a form of dispute resolution. The Court essentially reached into the medical deference model and reconfigured the external review system as a statemandated requirement for a third medical opinion, a formulation that had not been advanced by any of the parties or amici. ${ }^{159}$ It found that the external review process "does not resemble either contract interpretation or evidentiary litigation before a neutral arbiter, as much as it looks like a practice (having nothing to do

153. See, e.g., Brief for Respondent State of Illinois, supra note 131, at *24; Brief for the United States as Amicus Curiae, supra note 149, at *21; Brief of the American Medical Ass'n as Amici Curiae, supra note 150, at *22; Brief of the National Ass'n of Insurance Commissioners as Amicus Curiae, supra note 151 , at *18.

154. Brief for Petitioner at *22, Moran, 536 U.S. 355 (No. 00-1021), 2001 WL 1090765.

155. Reply Brief for Petitioner at *8, Moran, 536 U.S. 355 (No. 00-1021), 2001 WL 1590509.

156. Brief of American Ass'n of Health Plans, Inc. et al. as Amici Curiae in Support of Petitioner at *26, Moran, 536 U.S. 355 (No. 00-1021), 2001 WL 1077919.

157. Moran, 536 U.S. at 395 (Thomas, J., dissenting).

158. Id.

159. The AMA brief came the closest. See Brief of the American Medical Ass'n as Amici Curiae, supra note 150 , at $* 25$. 
with arbitration) of obtaining another medical opinion.... [It] is far removed from any notion of an enforcement scheme."160 The Court cautioned that its interpretation could vary, depending on the procedural regime of a particular external review system. ${ }^{161}$

Driven by the harshness of unremediable wrongs, the Court made the right decision for the wrong reason in Moran. The Court elected to stuff the complex reality of external review into the overly simple box of a "second opinion," rather than to reconsider the portion of Pilot Life which gave ERISA enforcement mechanisms overly broad reach. ${ }^{162}$ In 2004 the Court reaffirmed the scope of ERISA preemption, ruling that patients harmed by an MCO's wrongful denial of coverage for medically necessary care could not obtain damages based on state law. ${ }^{163}$

The Court's decision in Moran immeasurably increased the importance of external review laws by giving a green light for their continued and increased use. ${ }^{164}$ However, one ironic consequence of the Court's finding that external review systems are not a form of remedy could be to insulate them from due process review. The more distant a mechanism is from the basic adjudicatory function, the less likely it is that it will be scrutinized for procedural fairness, ${ }^{165}$ the very motivation for external review laws in the first place. Conversely, the presence of a more fully developed set of procedures within an external review system makes ERISA preemption more likely.

The first signal of weakness created by stronger procedural protections for patients came in Hawaii Management Alliance Ass'n v. Insurance Commissioner, ${ }^{166}$ in which the Hawaii Supreme Court held that ERISA preempted that state's external review law because it "too closely resemble[d] adjudication." 167 In distinguishing Moran the Hawaii court found it "fatal" to that state's system that it allowed judicial review of external review decisions, incorporated portions of the state's Administrative Procedure Act, established

160. Moran, 536 U.S. at 383.

161. Id. at 381 .

162. Pilot Life Ins. Co. v. Dedeaux, 481 U.S. 41, 52 (1987) (holding that the civil enforcement provision in ERISA is the exclusive remedy for enforcement of a right to benefits).

163. Aetna Health Inc. v. Davila, 542 U.S. 200 (2004).

164. Since Moran, external review laws in Texas and Maryland have been upheld against ERISA challenges. Corporate Health Ins., Inc. v. Tex. Dep't of Ins., 314 F.3d 784 (5th Cir. 2002); Conn. Gen. Life Ins. Co. v. Ins. Comm'r, 810 A.2d 425 (Md. 2002).

165. Richard C. Reuben, Constitutional Gravity: A Unitary Theory of Alternative Dispute Resolution and Public Civil Justice, 47 UCLA L. REv. 949 (2000).

166. 100 P.3d 952 (2004), cert. denied sub. nom. Baldado v. Haw. Mgmt. Alliance Ass'n, 125 S. Ct. 2524 (2005).

167. Id. at 966 . 
procedural requirements for hearings, and provided for review by a threemember panel. ${ }^{168}$ Numerous other state external review schemes include at least some of those same features. ${ }^{169}$

\section{B. External Review Systems-An Overview}

In forty-one states and the District of Columbia, legislatures have enacted laws establishing external review systems. ${ }^{170}$ Although the Court in Moran noted the varied nature of these laws, neither the Justices nor any of the parties or amici examined the most salient features of such laws, beyond the specifics of the Illinois statute. Had their variety been acknowledged, the Court would have had even more difficulty in casting aside the dispute resolution function which animates these laws.

In general, all of the state systems set forth rules for notification to the patient of an adverse determination, for what share of fees for the review is paid by each party, and for the time deadlines for each stage of the review process. ${ }^{171}$

168. Id.

169. See infra text accompanying notes $195-209,240-241$.

170. Alaska Stat. $\$ 21.07 .050$ (2004); ARIZ. Rev. STAt. ANN. $\$ 20-2537$ (West 2002); CAL. Health \& SafeTy Code $\S 1370.4$ (West 2000 \& Supp. 2005); Cal. Ins. Code $\S 10169$ (West 2005); Colo. Rev. Stat. ANN. § 10-16-113.5 (West 1999); ConN. Gen. Stat. § 38a-478n (2005); DEL. CODE ANN. tit. 16, $\$ 9119$ (2003); D.C. CODE ANN. § 44-301.07 (LexisNexis 2001); Fla. Stat. ANN. § 408.7056 (West 2002); GA. CODE ANN. §33-20A-39 (West 2002); Haw. Rev. STAT. $\S 432 \mathrm{E}-6$ (LexisNexis 2004); 215 Ill. Comp. Stat. ANN. 134/45 (West 2000); IND. CodE ANN. $\S 27-13-10.1-1$ (West 2003); Iowa Code ANN. $\S \S 514 J .1-514 J .15$ (West Supp. 2005); Kan. STAT. ANN. § 40-3228 (2000); Ky. REv. StAT. ANN. § 304.17A-623 (LexisNexis Supp. 2004); LA. ReV. Stat. ANN. §22:3081 (2004); Me. ReV. Stat. ANN. tit. 24-A, § 4312 (West Supp. 2004); MD. CODE ANN., INS. § 15-10A-05 (LexisNexis 2003); MASs. GeN. LAWS ANN. ch. 1760, § 14 (West Supp. 2005); Mich. Comp. Laws ANN. $§ \S 550.1901-550.1929$ (West 2002); MinN. STAT. AnN. $\S 62 Q .73$ (West 2005); Mo. ANN. STAT. § 376.1387 (West 2002); MONT. CODE ANN. § 33-31-303 (2003); N.H. REv. STAT. ANN. $\S$ 420-J:5-a to 420-J:5-e (LexisNexis 2004); N.J. ADMIN. CoDE $\S 8: 38-8.7$ (Supp. 2000); N.M. STAT. ANN. §59A-57-4 (Supp. 2004); N.Y. INs. LaW $§ 4914$ (McKinney 2000); N.C. Gen. Stat. §58-50-62 (2003); Ohio ReV. Code ANN. § 1751.85 (LexisNexis 2001); OKLA. STAT. ANN. tit. 63, $\S$ 2528.1-2528.10 (West 2004); OR. ReV. STAT. $\S \S 743.857-743.864$ (2003); 40 PA. CONS. STAT. ANN. $\$ 991.2162$ (West 1999); R.I. GeN. LAWs $\S 23-17.12-10$ (2001); S.C. CODE ANN. §§ 38-71-1910 to 38-71-2060 (2004); TENN. CODE ANN. $\S 56-32-227$ (2000); TEX. INS. CODE ANN. § 21.58C (Vernon 2004); UTAH CODE ANN. § 31 A-22629 (2001); VT. Stat. ANN. tit. 8, § 4089f (2001); VA. CODE ANN. § 38.2-5901 (Michie $1999 \&$ Supp. 2002); WASH. REV. CODE ANN. $\S 48.43 .535$ (West Supp. 2005); W. VA. CODE ANN. § 33 25C-6 (West 2002); WIS. STAT. ANN. $\$ 632.835$ (West 2004).

171. POLLITZ ET AL., supra note 95, at vii. Pollitz provides the best comparative analysis of the external review laws, but the report does not cite to specific statutory provisions. 
In nearly all states, a final external review decision that a benefit is covered by the policy is binding on the MCO,${ }^{172}$ although in two states there is a mechanism by which a health plan can opt out of participation in the external review system. ${ }^{173}$ Beyond those broad principles, however, there are many variations. ${ }^{174}$ The external review laws have produced finely-calibrated adjudication systems, as one sees by using traditional categories of procedural jurisprudence to describe them.

As in any adjudication system, jurisdictional authority is a threshold question. In all states an external review complaint can be brought against managed care plans, subject to the exemption for self-insured plans under ERISA; the majority of external review laws cover all insured health plans. ${ }^{175}$ Treatment decisions based on a determination that a particular service was not medically necessary are subject to review in all states; in addition, some state systems also review denials based on the assertion that a treatment was experimental or investigational, and thus not covered by the contract of insurance. $^{176}$

There is significant variation among the states in the standards of review for determining what is medically necessary. This is the most important point of law at issue in the external review systems, and the one as to which a body of external review decisions may ultimately have the greatest impact on health policy. The critical question is the extent to which external review mechanisms will force health plans to change how the necessity standard is applied to particular treatments.

At one end of the continuum, the MCOs receive considerable deference. North Carolina law specifically authorizes insurers to "compar[e] the costeffectiveness of alternative services or supplies." ${ }^{, 177}$ Several states explicitly limit

172. Neither party is bound by the external review decision in the District of Columbia. D.C. CODE $\$ 44-301.07(\mathrm{p})(2001)$.

173. In Oregon, the health plan can opt out of the external review system; if so, it must inform enrollees of that fact. OR. REv. STAT. $\$ \$ 743.859, .863, .864$ (2003). West Virginia allows a managed care plan to get an exemption from the system if it has "an established external review procedure in place." W. VA. CODE R. §114-58-12.1 (2002).

174. For state-by-state summaries of the laws, see Joyce Krutick Craig, Managed Care Grievance Procedures: The Dilemma and The Cure, 21 J. NAT'L Ass'N ADMIN. L. JudGes 336 (2001).

175. POLLITZ ET AL., supra note 95 , at 8-9.

176. Id. States differ as to how and by whom cases are screened for whether they present issues which are eligible for external review. Regulatory agencies perform this function in most states, but health plans do the screening in eight states. Id. at 16-17.

177. N.C. GEN. STAT. \$ 58-3-200(b) (2003). However, North Carolina law also guarantees that the external review will be conducted on a de novo basis. N.C. GEN. STAT. § 58-50-80(j) (2003). 
the scope of review by mandating that reviewers will be bound by the health plan's definition of medically necessary, ${ }^{178}$ an escape valve that could be used to render the review process a facade if plans succeeded in marketing contracts that simply excluded a large number of recurringly problematic disputes. In these states, the external review can be essentially limited to a check on whether the health plan complied with its own protocols. However, such language can be combined with language providing more latitude, as in West Virginia, where the ERO is limited to applying the terms of the plan, but regulations also define medical necessity to include "[t]he most appropriate available supply or level of service." 179 Moreover, regulators in some states may informally exercise discretion even when they are bound by the plan's definition. ${ }^{180}$

Other state laws have placed thumbs on the opposite end of the scale. Some states have created a rebuttable presumption in favor of the care recommended by the treating physician. Iowa, for example, requires that such treatment be upheld unless it is found to be neither medically necessary nor consistent with clinical standards of medical practice. ${ }^{181}$ Although contained in regulation rather than statute, District of Columbia law achieves the same end by defining medically necessary in terms of the treating physician's recommendation. ${ }^{182}$

These standards may at first appear to be pro-patient, but that reaction is based upon the assumption that external reviews arise when a treating physician's recommendation is vetoed by the managed care entity. While that situation is not uncommon, the dispute may also arise between a treating physician, possibly receiving a financial incentive to underutilize care, and an outside specialist secured by the patient, as was the case in Moran, ${ }^{183}$ in which case the impact of the rebuttable presumption in favor of the treating physician could favor the insurer.

Redefinition of medical necessity definitely occurs. Washington grants external review entities specific statutory authority to override the health plan's medical necessity standards if they are determined "to be unreasonable or inconsistent with sound, evidence-based medical practice." ${ }^{184}$ It is unclear whether such a finding could be utilized in a subsequent claim for malpractice

178. Alaska Stat. § 21.07.050(d)(1) (2004); ARIZ. Rev. Stat. AnN. § 20-2537(E) (2002); KAN. STAT. ANN. §40-22a14(b) (2000); OR. ReV. STAT. § 743.862(2) (2003) (unless plan's definition is "unreasonable"); TENN. CODE ANN. §56-32-227(b)(6) (2000); WIS. STAT. ANN. $\S 632.835(3 \mathrm{~m})$ (West 2004).

179. W. VA. CODE R. § 114-58-5.5 (2002).

180. Berman-Sandler, supra note 9 , at 268-69.

181. IowA Code ANN. $\S 514 J .12$ (West Supp. 2005).

182. D.C. MUN. Regs. tit. 22, §6099.1 (2005).

183. See supra text accompanying note 133.

184. WASH. Rev. Code ANN. § 48.43.535(5) (West Supp. 2005). 
against an $\mathrm{MCO}$, not merely a physician, based on corporate negligence in standard-setting. In practice Michigan allows an external review decision to deviate from the terms of the contract if the medically necessary standard is being applied in an obsolete or unworkable fashion. ${ }^{185}$

A number of states do not address the degree of deference to be shown to a health plan's definition of medically necessary, but instead invoke general concepts of consistency with accepted standards of medical practice and professionally established protocols, such as Minnesota's definition of medically necessary care as "health care services appropriate, in terms of type, frequency, level, setting and duration, to the enrollee's diagnosis or condition, and diagnostic testing and preventive services." 186 Some states look to the "most appropriate available supply" relevant for the particular treatment, ${ }^{187}$ or require compliance with "scientific evidence" as to the usefulness of disputed services. ${ }^{188}$ Regulations in Vermont specify that the ERO is "not bound by the insurer's clinical protocols or practice guidelines." ${ }^{189}$ About half of the states with external review systems allow not only for reversal or affirmation of the health plan's denial but also for modification, perhaps to allow some portion of the treatment being sought. ${ }^{190}$

The Georgia statute exemplifies the final option used by states, which is to craft an exceedingly detailed definition of medical necessity solely for external review purposes. Georgia defines medical necessity as

care based upon generally accepted medical practices in light of conditions at the time of treatment which is: (A) Appropriate and consistent with the diagnosis and the omission of which could adversely affect or fail to improve the eligible enrollee's condition; (B) Compatible with the standards of acceptable medical practice in the United States; (C) Provided in a safe and appropriate setting given the nature of the diagnosis and the severity of the symptoms; (D) Not provided solely for the convenience of the eligible enrollee or the convenience of the provider or hospital; and (E) Not primarily custodial care, unless custodial care is a covered service or benefit under the eligible enrollee's coverage. ${ }^{191}$

185. Berman-Sandler, supra note 9 , at 268 .

186. MINN. R. 4685.0100(9)(b) (2005).

187. MASS. REGis. CODE tit. 105, $\$ 128.020$ (2005).

188. Id.

189. 21 -040-012 VT. CODE R. \$7(B) (2004).

190. POLlitZ ET AL., supra note 95, at 18-19.

191. GA. CODE ANN. $\$ 33-20 A-31(5)$ (2000 \& Supp. 2003). Maine also has a highly specific, although less complex, statutory definition. ME. REv. STAT. ANN. tit. 24-A, $\$ 4301-A(10-A)$ (Supp. 2003). 
A number of states specify that the external review shall be conducted as a de novo review. ${ }^{192}$ The critical question of which party has the burden of proof is left unanswered in every state except Maryland, ${ }^{193}$ which assigns it to the managed care entity.

What follows is a detailed description of the procedural workings of external review systems. Here, however, the devil is not in the details. Although the particularities are necessary to an understanding of the broader themes, the greatest significance of external review laws is that they illuminate what are the currently dominant norms and values related to adjudication. External review laws tell us that faith in adjudication has not only failed but collapsed. ${ }^{194}$ Imagine a game of "Legal Jeopardy" with this problem: If external review is the answer, what is the question? The correct response: If legislators starting from scratch invented an adjudication system today, what would it look like?

\section{Evidence and Hearings}

Some statutes, especially those which require consistency with accepted standards of practice, specify what evidence can or must be considered in the ERO's decision-making process. ${ }^{195}$ In some states external reviewers are required

192. ALASKa STAT. $\$ 21.07 .050$ (d)(1) (LexisNexis 2000); MASS. GEN. LAWS ANN. ch. 1760, $\S 14(a)$ (West Supp. 2005); Mich. Comp. Laws ANN. § 550.1911(8) (West 2002); MinN. STAT. ANN. § 62Q.73(7) (West 2004); N.H. ReV. STAT. ANN. § 420-J:5-b(IX) (2004); N.C. Gen. STAT. § 58-50-80(j) (2003); OHIO REV. CODE ANN. § 1751.84(E) (Anderson 2004); S.C. CODE ANN. § 3871-1970(D)(2) (2002); 14 VA. ADMIN. CODE $\$$ 5-215-70(b) (2005).

193. MD. CODE ANN., INS. § 15-10A-05 (LexisNexis 2002).

194. The "failure" reference is to Judith Resnik, Failing Faith: Adjudicatory Procedure in Decline, 53 U. CHI. L. REv. 494 (1986).

195. A typical provision states:

[A]n independent review entity ... shall take into account all of the following:

(a) Information submitted by [a party] including:

1. The covered person's medical records;

2. The standards, criteria, and clinical rationale used by the insurer to make its decision; and

3. The insurer's health benefit plan.

(b) Findings, studies, research, and other relevant documents of government agencies and nationally recognized organizations [giving examples]; and

(c) Relevant findings in peer-reviewed medical or scientific literature, published opinions of nationally recognized medical specialists, and clinical guidelines adopted by relevant medical societies.

Ky. Rev. Stat. AnN. § 304.17A-625(1) (LexisNexis 1996 \& Supp. 2004). 
to consider evidence in each listed category; ${ }^{196}$ in other states they are merely authorized to do so. ${ }^{197}$ Other states, like Alaska, specify both, listing certain categories of evidence which must be considered and others that are discretionary. ${ }^{198}$

Several states have established procedures for information-sharing between the parties that parallel discovery. Health plans may have an affirmative duty to send the patient a copy of any documents that it submits to the external reviewer, including clinical review criteria, unless the documents contain proprietary information. ${ }^{199}$ Other states provide patients a right to see all evidence in the case, but do not impose a duty on the health plan to furnish it to them; ${ }^{200}$ in New York and Oklahoma, patients may see the evidence upon request. ${ }^{201}$ EROs in West Virginia have subpoena power. ${ }^{202}$

In general, external review systems conduct exclusively paper reviews, but there are, nonetheless, a wide variety of provisions regarding in-person hearings before which the patient or her representative can appeal. In some states the external review proceeding is a function of a state agency, so that the final decision is an agency decision, even if it consists only of a commissioner's approval of the decision of a private external review organization. In those states the possibility of a hearing may be governed by the state's body of administrative law, or there may be an explicit provision for the external review process. ${ }^{203}$ In Missouri external reviews of treatment denials are specifically excluded from the provision of state administrative law that would require a hearing. ${ }^{204} \mathrm{~A}$ hearing "may" be held in Maryland and New Hampshire. ${ }^{205}$

196. See, e.g., id:; N.H. Rev. Stat. Ann. §420-J:5-b(IX) (2004); Ohio Rev. Code Ann. $\S 1751.84(\mathrm{D})(8)$ (LexisNexis 2004).

197. See, e.g., LA. Rev. STAT. ANN. $\$ 22: 3082($ A) (West 2004).

198. Alaska Stat. § 21.07.050(d)(3), (4) (2004).

199. See, e.g., Ga. Code Ann. §33-20A-36(3) (2000); 3 Colo. Code Regs. § 4-2-21(8)(C)(2) (2005).

200. See, e.g., Mass. Regs. Code tit. 105, $\$ 128.403$ (B) (2005); N.H. Rev. Stat. AnN. $§ 420-$ J:5-b(VII) (LexisNexis 2004); N.C. Gen. STAT. $\$ 58-50-80(d)(3)$ (2003); TENN. CODE ANN. 56-32227 (b)(3)(B) (2000).

201. N.Y. Ins. LaW $\$ 4912(\mathrm{~g})$ (McKinney 2000); OKLa. Stat. AnN. tit. 63, $\$ 2528.7$ (B) (West 2004).

202. W. VA. CODE ANN. § 33-25C-6(m) (LexisNexis 2003).

203. Patients in Florida and New Mexico have a right to an administrative hearing. See FLA. STAT. ANN. \$ 408.7056(3) (West 2002); N.M. CODE R. § 13.10.17.31(A) (Weil 2005).

204. MO. ANN. STAT. $\$ 376.1387(1)$ (West 2002), exempting external review from Mo. ANN. STAT. $\$ 536.010$ (West 2000).

205. MD. CODE ANN., INS. § 15-10A-04(a)(3) (2002); MD. COdE Regs. 31.10.18.15(B); N.H. REV. StAT. ANN. \$ 420-J:5-b(IV)(a) (LexisNexis 2004). 
Among the majority of states where the final decision emerges from the external review organization without adoption by a state agency, only the District of Columbia and Maine provide for the patient to appear at a hearing and present evidence. ${ }^{206}$ Vermont law provides for a teleconference if the patient requests one. ${ }^{207}$ Massachusetts leaves the question of whether to hold an in-person hearing to the discretion of the reviewer. ${ }^{208}$ Wisconsin explicitly forbids appearances before the ERO by a party, a party's representative, or a witness. ${ }^{209}$

In the four states in which she interviewed regulatory officials, BermanSandler found a pattern of mostly paper-only review, similar in form to alternative dispute resolution, but with the "plaintiff" retaining the right to sue. ${ }^{210}$ Extensive contacts have developed between state agencies and the independent review companies, with staff of the former reporting increasingly higher quality levels for the work done by the latter. ${ }^{211}$ Attorneys are seldom involved; their presence tends to occur, predictably, only in big-dollar cases. ${ }^{212}$ On the whole she found that external review "looks like a [state agency's] consumer protection and complaint system . . . assess[ing] whether a health plan has followed prescribed regulatory conduct. The review of conduct includes elements of procedural due process ...."213

\section{Selection and Structure of the EROs}

Independence and impartiality on the part of adjudicators is a cardinal principle in American law. ${ }^{214}$ Most states include provisions prohibiting conflicts of interest between EROs and their staff and the MCOs which are the source of the claims denials being reviewed, as well as any conflicts that might arise as to particular individual patients or their primary care physicians. ${ }^{215}$ Most states have some procedure for designating or certifying which entities may operate as EROs for appeals within that state. ${ }^{216}$ In a number of instances, review entities that have

206. D.C. CODE ANN. §44-301.07(k) (LexisNexis 2001); ME. Rev. Stat. ANN. tit. 24-A, $\S 4312(5)$ (B) (West Supp. 2004).

207. 21-040-012 VT. CODE R. § 7(C) (2004).

208. MASS. ANN. LAWS ch. $1760, \S 14$ (West Supp. 2005).

209. Wis. Stat. ANN. 632.835(3)(d) (West 2004).

210. Berman-Sandler, supra note 9 , at 256-57.

211. Id. at 258 .

212. Id. at 261-62.

213. Id. at 257 .

214. The mechanisms described in this paragraph are discussed in Craig, supra note 174; POLLITZ ET AL., supra note 95, at 16-18.

215. Pollitz ET AL., supra note 95, at 17-18.

216. Berman-Sandler, supra note 9, at 239. 
been accredited by a private accreditation agency are deemed to be certified. ${ }^{217}$

There is greater variance in the statutory requirements as to who selects which ERO will review which claim and in the degree of oversight of the EROs. The majority of states provide for an ERO to be assigned to each appeal by a state regulatory office. However, fourteen states allow the health plan to exercise some degree of control over the selection of the ERO. ${ }^{218}$ In ten states the health plan simply gets to choose which ERO will hear the case. ${ }^{219}$ In Ohio the plan chooses one of two EROs recommended by the state. ${ }^{220}$ In Oregon the plan can reject the state's selection of an ERO once in any proceeding. ${ }^{221}$ Illinois and Montana both provide that the patient and the plan will jointly select the ERO, ${ }^{222}$ although it is difficult to imagine that the patient, unless represented by counsel with substantial external review experience, would be able to make an informed choice. The same problem would be true also in Wisconsin, where the patient

217. See, e.g., Colo. Rev. Stat. ANN. §10-16-211(11)(F)(West 1999).

218. AlASKA STAT. \$21.07.050(c) (LexisNexis 2004); InD. CODE ANN. \$27-13-10.1-2 (LexisNexis 1999); IOWA CODE ANN. \$514J.7(1)(a) (West Supp. 2002); KY. Rev. Stat. ANN. $\S \S 304.17$ A-623(7), -627 (LexisNexis 2004); 806 Ky. Admin. ReGS. 17:290 (2005); LA. Rev. STAT. ANN. $\$ 22: 3082($ A) (2004); LA. AdMIN. CODE tit. 37, pt. XIII, $\$ 6227$ (A) (2005); OKLA. STAT. ANN. tit. 63, $\$ 2528.6$ (B) (West 2004); S.C. CODE ANN. $\$ 38-71-1970$ (B)(1)(a) (2002); TENN. CODE ANN. $\S 56-32-227$ (a) (2000); UTAH CODE ANN. \$31A.22-629(1)(b)(iii) (2003); UTAH ADMIN. CODE R590-203-6(3) (2005); WASH. Rev. CODE ANN. § 48.43.535(3) (West Supp. 2005). In Iowa and Oklahoma, the patient can object to the state regulatory agency if she believes the ERO to be biased. In Tennessee patients may file appeals either with a state agency, in which case agency staff conduct the review, or with their health plan, in which case the plan selects the reviewer. OHIO REV. CODE ANN. $\S 3901.80$ (c) (Anderson 2002). OR. REV. STAT. $\$ 743.858$ (2003). 215 ILl. COMP. STAT. ANn. 134/45(f)(3)(A) (West 2000); Mont. Code AnN. \$33-37-103 (2003); Mont. Admin. R. 37.108.305(1) (2005). In Montana the state agency will select an ERO if the parties cannot agree.

219. ALASKa STAT. §21.07.050(c) (LexisNexis 2004); IND. CODE ANN. \$27-13-10.1-2 (LexisNexis 1999); Iowa Code ANN. §514J.7(1)(a) (West Supp. 2002); Ky. Rev. STAt. ANN. $\S \S 304.17 \mathrm{~A}-623(7)$ ), 304.17A-627 (LexisNexis 2004); $806 \mathrm{KY}$. AdMIN. Regs. 17:290; LA. Rev. Stat. ANN. § 22:3082(A) (2004); LA. Admin. COdE tit. 37, pt. XIII, §6227(A) (2005); OKLA. STAT. ANN. tit. 63, § 2528.6(B) (West 2004); S.C. CODE ANN. \$38-71-1970(B)(1)(a) (2002); TENN. CODE ANN. § 56-32-227(a) (2000); UTAH CODE ANN. §31 A.22-629(1)(b)(iii) (2003); UTAH ADMIN. CODE R590-203-6(3) (2005); WASH. REV. CODE ANN. § 48.43.535(3) (West Supp. 2005). In Iowa and Oklahoma, the patient can object to the state regulatory agency if she believes the ERO to be biased. In Tennessee patients may file appeals either with a state agency, in which case agency staff conduct the review, or with their health plan, in which case the plan selects the reviewer.

220. OHIO REV. CODE ANN. § 3901.80(c) (Anderson 2002).

221. OR. REV. STAT. $\$ 743.858(2003)$.

222. 215 Ill. Comp. Stat. AnN. 134/45(f)(3)(A) (West 2000); MONT. CODE ANN. \$33-37-103 (2003); MONT. ADMIN. R. 37.108.305(1) (2005). In Montana the state agency will select an ERO if the parties cannot agree. 
alone makes the selection. ${ }^{223}$

The issue of control over selection of the decision-maker is all the more critical in external review because of the open-ended nature of most of the standards that will be used. There are obviously serious problems with a system in which one party, with the advantages of repeat-player status, could develop unspoken relationships and understandings with private judges before whom the plan will appear again and again.

\section{Remedies, Precedent, and Further Proceedings}

\section{a. Remedies and Precedent}

The basic remedies from external review are simple. A patient who appeals a denial of treatment is entitled, in most states, to a written decision. The successful patient is entitled to an order directing the health plan to provide (or pay for, if it is a retrospective case) the treatment which was initially denied. No monetary damages are awarded in any external review system. Interim relief is available in Massachusetts and Washington state, where EROs can order the plan to continue providing a service pending the external review decision. ${ }^{224}$

Several statutes have language designed to insure that the decision is written in clear language, understandable to the layperson. ${ }^{225}$ Michigan requires a "plain English" explanation of the basis for the decision. ${ }^{226}$ In several states, the decision must list the evidence which was considered by the panel and relied on as the basis for the decision. ${ }^{227}$

Perhaps the single most remarkable characteristic of the external review systems, from a due process point of view, is the absence of precedent. With three exceptions, there is no readily accessible body of prior written decisions. Public availability is required by law only in Oregon, which posts redacted versions of decisions on a web site. ${ }^{228}$ California and Michigan have elected to do

223. WIS. STAT. ANN. $\$ 632.835(3)$ (a) (West 2004).

224. MASS. ANN. LAwS ch. 1760, $\S 14$ (b) (LexisNexis 2002) (requiring showing of substantial harm); WASH. REV. CODE ANN. $\S 48.43 .535(8)$ (West Supp. 2005) (stating that if the health plan wins the appeal, it can seek recoupment from the patient of the expense of the service).

225. See, e.g., KY. REv. Stat. ANN. § 304.17A-625(6) (LexisNexis 2004); 105 MASs. CODE REGS. § 128.415(B) (2005); S.C. CODE ANN. § 38-71-1970(H)(3) (West 2002).

226. Mich. COMP. LAwS ANN. $\S 550.1911(16)$ (West 2002).

227. See, e.g., Mont. Admin. R. 37.108.305(3) (2005); N.H. ReV. StAT. ANN. § 420-J:5b(X) (LexisNexis 2004).

228. OR. Rev. Stat. § 743.862(5) (2001); Or. AdMIN. R. 836-053-1355 (2005) 
the same. ${ }^{229}$ Decisions which go through an administrative agency may be accessible through other means. ${ }^{230}$ Kentucky's law addresses the question of precedent in a different way, by specifying that the effect of each decision will be limited to that one case only. ${ }^{231}$

Thus, precedent can build up or affect future or other cases only on an informal basis. This situation creates an enormous imbalance between the parties: repeat players, most often the MCOs, can create and maintain their own compilations of decisions and use them as guidance. Only individuals who pursue appeals with the assistance of similarly-organized representatives would have a comparable information base. The absence of publicly-accessible statements of reasons for external review decisions also fundamentally disables systemic oversight of health plans.

\section{b. Further Review and Litigation}

One major mitigating factor for all of the due process deficiencies in external review systems is that, as a general matter, patients can subsequently bring suit against the health plan for injuries caused by the denial of treatment. ${ }^{232}$ However, the law shapes the effect that an external review decision could have on a later lawsuit in a number of ways, some of which would bar litigation.

In West Virginia, the plaintiff must have gone through and prevailed in the external review process in order to bring suit. ${ }^{233}$ In seven other states the plaintiff must have first pursued external review before she can litigate. ${ }^{234}$ In yet other states the outcome of the external review creates a rebuttable presumption in a

229. See Cal. Dep't of Managed Health Care, Independent Medical Review Decisions, http://wp.dmhc.ca.gov/imr (last visited Nov. 1, 2005); Mich. Dep't of Labor \& Econ. Growth, Labor \& Economic Growth, http://www.michigan.gov/cis/0,1607,7-154-10555_20594_20596-,00.html (last visited Nov. 1, 2005).

230. In Arizona external review determinations become "final administrative decisions" which can be obtained in the same way as other administrative decisions. ARIZ. REV. STAT. ANN. $\S 20-$ $2537(\mathrm{H})(2002)$. A newspaper was able to obtain redacted copies of the decisions in Maryland through a freedom of information request to the Insurance Administration. Bill Brubaker, Health Insurance Consumers Wield the Power of Appeal, WASH. POST, July 3, 2004, at E1 .

231. KY. Rev. Stat. ANN. \$ 304.17A-625(3), (9) (LexisNexis Supp. 2004).

232. As a practical matter, however, this option may not offer much relief. Persons insured through a private sector workplace plan can bring suit only under ERISA, under which they can recover only actual expenses and attorneys fees. 29 U.S.C. $\$ 1132$ (a) (2000).

233. W. VA. CODE ANN. \$33-25C-7(e) (LexisNexis 2002).

234. Cal. Civil Code $\$ 3428(\mathrm{k})(1)$ (West 2004); GA. Code AnN. $\$ 51-1-49$ (2000); ME. Rev. Stat. AnN. tit. 24-A, $\$ 4313(2)(B)(2003)$; Okla. Stat. AnN. tit. 36, $\$ 6594(A)$ (West 2004); 14 000-016 R.I. CODE R. \$6.1.12 (Weil 2005); TeX. CIV. PraC. \& Rem. \$ 88.003(a)(2)(B) (Vernon 2005); WASH. REV. CODE ANN. $\$ 48.43 .545(7)(a)(i i)$ (West Supp. 2005). 
later lawsuit. ${ }^{235}$ Some states specify that an external review decision is admissible in subsequent proceedings, ${ }^{236}$ Kentucky courts must accept the decision as "scientifically valid and accurate." 237 At the other extreme South Carolina bars its use as evidence, ${ }^{238}$ and the District of Columbia specifies that the decision "shall not affect any other legal cause of action." 239

Most state laws do not provide for further appeal of the external review decision itself. Exceptions are Alaska, Delaware, Michigan, Minnesota, New Mexico, Pennsylvania, and Rhode Island. ${ }^{240}$ Some states limit judicial review only to "arbitrary and capricious" decisions by an ERO. ${ }^{241}$

\section{Utilization and Reversal Rates}

Differences in jurisdiction, definitions, and reporting make it difficult to assess the extent to which patients actually utilize external review systems. The Kaiser Family Foundation and American Association of Health Plans found a national average of 0.7 reviews per 10,000 enrollees, but that average was derived from an enormous range: from 0.2 to 1.7 per $10,000 .{ }^{242}$ There are no national data on the number of external review appeals filed. In the four states that she examined in detail, Berman-Sandler found a pattern of rapid growth in the early years of external review, followed by a leveling off of the number of appeals. From 1999 to 2002 in those states, 5129 cases entered the external review systems. ${ }^{243}$ There are large variations among the states. In the four largest states, in the most recent year for which data were available in 2004, California

235. Colo. Rev. Stat. AnN. §10-16-113.5(11) (West 1999); Ga. Code AnN. § 33-20A-37(b) (2000) (presumption available only to a prevailing MCO); Mo. ANN. STAT. $\$ 376.1387$ (1) (West 2002); 40 PA. STAT. ANN. $\S 991.2162$ (c)(5) (West 1999).

236. Ariz. Rev. Stat. AnN. §20-2537(J) (2002); Ky. Rev. Stat. Ann. §304.17A-625(8) (LexisNexis 2004); N.C. Gen. STAT. ANN. §90-21.55(a) (West 2003); OHIo Rev. Code ANN. $\S 1751.88$ (West 2004).

237. Ky. Rev. Stat. ANN. § 304.17A-625(8) (LexisNexis 2004).

238. S.C. CODE ANN. § 38-71-1990(B) (2002).

239. D.C. CODE ANN. $\$ 44-301.07$ (p) (LexisNexis 2001).

240. Alaska Stat. $\$ 21.07 .050(d)(8)$ (Michie 2004); Del. Code AnN. tit. 18, $\$ 332$ (1999); Mich. Comp. LAws ANN. § 550.1915(1) (West 2002); MinN. STAT. ANN. § 62Q.73(8) (West 2005); N.M. Stat. ANN. § 59A-4-20 (Michie 2002); 40 PA. Cons. Stat. ANN. § 991.2162(c)(5) (West 2005); R.I. GEN. LAWS § 23.17.12-10(b)(6) (2001).

241. See, e.g., MINN. STAT. ANN. §62Q.73(8) (West 2005).

242. Berman-Sandler, supra note 9, at 249.

243. Berman-Sandler, supra note 9, at 301-02 app. B, ch. II. This total includes 528 cases decided in the Pennsylvania system, which did not report a number for "cases accepted." These numbers can serve as only a rough gauge because the start date for external review varied in each of the states. 
processed 586 cases; New York adjudicated 796 external reviews; Texas decided 231 cases; and Florida reported only $29 .{ }^{244}$ In Maryland 280 cases went into external review in fiscal year $2003,{ }^{245}$ while in the two much larger states of Michigan and Ohio, the most recent annual numbers were 129 and 176 , respectively. ${ }^{246}$

Observers have consistently found serious problems in access to external review, growing primarily from the requirement that the plan's system of internal reviews be exhausted and from failures to effectively communicate to patients how external review works or even that it exists. ${ }^{247}$ The Kaiser Family Foundation report criticized this exhaustion of remedies requirement, together with weak notice provisions, for resulting in many fewer appeals than would otherwise be the case, because patients may be required to go through one or even two levels of internal review, and sometimes are not told that external review exists until they have completed internal review. ${ }^{248}$

A study of the California system, the most detailed examination of the workings of an external review system, found an enormous drop-off in the number of complaints regarding denials of care and the number that ultimately went to independent review: from 6127 to $299 .{ }^{249}$ Even in the same state, there was a huge difference among the six plans' studies: Rates ranged from three to twenty-five percent of complaints proceeding to external review. ${ }^{250}$ Two-thirds of

244. Cal. Dep't of Managed Health Care, Independent Medical Review DETERMINATIONS, available at http://www.hmohelp.ca.gov/imr/stats.pdf; N.Y. STATE DEP'T OF Ins., New York State External Appeal Program 2002, at 27, available at http://www.ins.state.ny.us/acrobat/extapp02.pdf; TEX. OfFICE OF PUB. INS. CounsEl, COMPARING TEXAS HMOS 2003, at 109, available at http://www.opic.state.tx.us/docs/238 printout2003hmo.pdf; Fla. Agency for Health Care Admin., Statewide Provider and Health Plan Claim Dispute Resolution Program, Annual Report 2004, at 3, available at http://www.fdhc.state.fl.us/MCHQ/Managed_Health_Care/SPHPClaimDRP/Annual_Report_2004. pdf. These figures include only medical necessity cases in states where experimental treatment decisions are also reviewed.

245. Brubaker, supra note 230.

246. Mich. Office of Financial \& Ins. Servs., HMO Complaint Information, http://www.michigan.gov/documents/cis_ofis_compinfo_28032_7.html (last visited Oct. 29, 2005); Jane DuBose, Healthleaders, Ohio's External Review Experience, (July 2, 2004), http:// www.healthleaders.com/news/feature56164.html.

247. POLlitz ET AL., supra note 95, at vii, 8-14; Berman-Sandler, supra note 9, at 247-53.

248. POLLITZ ET AL., supra note 95, at 5-7, 10, 12; see also Berman-Sandler, supra note 9, at 247-53.

249. Jill K. Silverman et al., Inst. For MEd. Quality, Independent Medical Review Experiences in California, Phase II: Cases InCluding Medical Necessity $36-37$ (2003) [hereinafter IMR 2003].

250. Id. 
patients were unaware of the system until their individual cases arose, ${ }^{251}$ and a majority of them were not informed of the deadlines that applied. ${ }^{252}$ These data do not tell us whether further appeals were not pursued because patients were satisfied with the outcome or because of problems with access. However, in the Medicare program, where appeals are automatic rather than contingent on patient filings, the rate of utilization is dramatically higher than in state external review programs. $^{253}$

When patients make it as far as the external review system in a state, they have a significant win rate. Although it is impossible to evaluate what any reversal rate means, or whether it means anything more than survival of the strongest cases, patients who appeal do have a meaningful chance of success. In the largest states, external review panels reversed denials of care approximately forty percent of the time. ${ }^{254}$

\section{Non-Judicial Conferences: The Framers of External Review}

The structure of the state external review laws, with their components modeled on the components of a dispute resolution process, make clear that these systems are not merely commands to secure an additional physician's opinion, as the Supreme Court's majority described them in Moran. Although external review systems can fairly be described in part as attempts to restore some deference to medical authority, the states accomplished the restoration by means of an adjudication system. The primary voices in the debates over enacting these laws were not those whom we think of as proceduralists, such as judges or law professors, but those of the interest groups directly in conflict. Because of that, the tradition that the process of making process ${ }^{255}$ should be a function of neutral experts did not carry over into the process of making external review systems. ${ }^{256}$

251. Id. at 12 .

252. Id. at 14.

253. Karen Pollitz et al., Inst. for Health Care Res. \& Pol'y, External Review of health Plan Decisions: an Overview of Key Program features in the States and MEdiCARE, at iv-v, viii, 17-18 (1998).

254. Berman-Sandler, supra note 9, at 256.

255. The phrase is Robert Bone's. Robert G. Bone, The Process of Making Process: Court Rulemaking, Democratic Legitimacy, and Procedural Efficacy, 87 GEO. L.J. 887 (1999).

256. Beginning with the Rules Enabling Act in 1934 and the adoption of the Rules in 1938, Congress has delegated primary responsibility for the adoption and revision of the Rules of Civil Procedure to the Supreme Court. The prevailing understanding was that in vesting this power in the Court rather than in Congress or the Justice Department, "Congress placed rulemaking under the institution it perceived to be least responsive to interest group politics." Paul D. Carrington, Making Rules To Dispose of Manifestly Unfounded Assertions: An Exorcism of the Bogy of Non-Trans- 
Instead, the enactment of external review laws illustrates the emergence of openly adversarial proceduralism.

The central players in the legislative battles fell into five general camps: insurance and other business interests who sought to limit the scope and extent of review; consumer groups who sought to maximize it; medical groups who sought to shift, or at least share, potential malpractice liability with managed care organizations; governmental regulatory agencies; and private organizations that accredit health care organizations. ${ }^{257}$ Stakeholders engaged in debates over external review based on bottom-line interests. ${ }^{258}$ Consumer advocates proposed

Substantive Rules of Civil Procedure, 137 U. PA. L. REv. 2067, 2075 (1989). In turn, the Court shared its authority with the Judicial Conference and subordinate committees, a structure thought to be "substantially immunized from the possibility of influence resulting from direct interest or coercive pressures brought to bear by organized groups." Id at at 2077.

In recent years, the mask of neutrality has fallen away from the court rule-making model. Openly interest-based advocacy began in earnest in the 1980s, and has continued, especially in hard-fought contests over Rule 11 and the rules governing discovery. See Bone, supra note 255, at 903-04; Richard L. Marcus, Of Babies and Bathwater: The Prospects for Procedural Progress, 59 BRook. L. ReV. 761, 805-12, 819 (1993); Linda S. Mullenix, Hope over Experience: Mandatory Informal Discovery and the Politics of Rulemaking, 69 N.C. L. REv. 795, $851-55$ (1991); Kent Sinclair, Service of Process: Rethinking the Theory and Procedure of Serving Process Under Federal Rule 4(c), 73 VA. L. REv. 1183, $1197-212$ (1987); Jeffrey L. Stempel, Politics and Sociology in Federal Civil Rulemaking: Errors of Scope, 52 ALA. L. Rev. 529 (2001); Jeffrey L. Stempel, New Paradigm, Normal Science, or Crumbling Construct? Trends in Adjudicatory Procedure and Litigation Reform, 59 BROOK. L. REv. 659 (1993).

257. The Senate Committee on Health, Education, Labor and Pensions heard testimony in 1998 on "health care quality: grievance procedures" and in 1999 on "key patients' protections." A total of fifteen witnesses testified at the two hearings. Health Care Quality: Grievance Procedures: Hearing on S. 326 Before the S. Comm. on Health, Education, Labor, \& Pensions, 105th Cong. (1998) (witness list); Key Patients' Protections: Lessons from the Field: Hearing on S. 326 Before the S. Comm. on Health, Education, Labor, \& Pensions, 106th Cong. (1999) (witness list). They included six government officials, five industry representatives, three consumer representatives, and one medical spokesperson. There was no testimony from a bar association or other legal representative or from anyone representing the standpoint of procedural expertise. Id. In its evaluation of HMO complaints and appeals procedures, the GAO identified one industry group, one consumer group, the association of state insurance regulators, and two private accrediting organizations as the most influential advocates involved in the issue. GAO REPORT, supra note 95.

258. Shirley Eiko Sanematsu, Taking a Broader View of Treatment Disputes Beyond Managed Care: Are Recent Legislative Efforts the Cure?, 48 UCLA L. REv. 1245, 1263 (2001) ("The reason most often cited for the [California] legislation was to curb managed care's profit-making incentive to deny care."); Nathaniel S. Shapo, In the Eye of the Storm: A Regulator's Perspective on Managed Care Organization Liability, 30 J. LEGAL STUD. 669, 683 (2001) ("view[ing] the MCO liability debate [in Illinois] through the prism of interest group politics, where the clash between MCOs and doctors' groups is extraordinar[ily] hostile"); Lisa Strauss, Managed Healthcare Plans, 
external review laws as vehicles for inserting a patients' rights orientation into the administration of managed care to balance cost containment incentives, with procedural design oriented toward that goal; and physicians sought reinstatement of at least some of their power vis-à-vis payors. The response of the insurance industry was mixed: initially negative, then increasingly supportive of external review as a relatively inexpensive way to curb litigation and limit liability. ${ }^{259}$ When the idea of external review reached Congress, debate centered on its usefulness for decreasing litigation ${ }^{260}$ and the impact of lawsuits on the managed care industry. ${ }^{261}$

Although counter to the norm of rule neutrality, this transparently pluralist negotiation of an adjudication mechanism has advantages. Direct interest group negotiation leads to a balancing of the real interests in play, rather than hiding them behind a screen of what is sometimes false objectivity.

Openly pluralist negotiation of procedure also has its costs, however. Even though judicial authors do not guarantee impartial rules of procedure, the court rule-making model reflected in the Federal Rules provides certain institutional constraints. Judges and others more detached from interest group advocacy

16 GA. ST. U. L. REV. 151, 152 (1999) (describing Georgia external review law as "a political compromise between managed care, business lobbyists, and the Governor"); Louise G. Trubek, Public Interest Lawyers and New Governance: Advocating for Health Care, 2002 WIS. L. REv. 575, 590-92, 596 (describing negotiations over bill between consumer-physician alliance and MCOs in Wisconsin and positions on external review).

259. Scott Thornton, Comment, The Texas Health Care Liability Act: Managed Care Organizations Can Say Goodbye to Their Extensive Immunity from Lawsuits-Or at Least That Was How It Was Supposed To Work, 30 TEX. TECH. L. Rev. 1227, 1271 (1999). As part of class action settlements, several insurers, including Aetna, CIGNA, Health Net, and Anthem/Wellpoint, have agreed to establish separate external review boards for appeals by physicians. See Conn. State Med. Soc'y, Aetna Settlement Summary, http://csms.org/content/showpage.asp?page=news 17 (summarizing the terms of settlement reached in multi-district litigation in the Southern District of Florida); Conn. State Med. Soc'y, CIGNA Settlement Summary, http://csms.org/content/ showpage.asp?page=news 18 (same); Conn. State Med. Soc'y, Health Net Settlement Summary, http://csms.org/content/showpage.asp?page=news19 (same); Conn. State Med. Soc'y, Anthem/Wellpoint Settlement Summary, http://csms.org/content/showpage.asp?page=news20 (same). See generally Ceci Connolly, Insurer Agrees To Pay Doctors \$198 Million, WASH. POST, July 12,2005 , at A2.

260. The dispute centered on whether other restraints on litigation should be imposed as well. Stephanie Lewis, The Henry J. Kaiser Family Found., A Guide to the Federal Patients' Bill OF Rights DEBATE 6-9 (2001).

261. Perhaps the most colorful articulation of the defense against such lawsuits came from Senator Phil Gramm (R-Tex.), who told the Senate, "I have seen people healed in hospitals, doctors' offices, clinics. I have even seen people healed in tent revivals. But I have never, ever seen anybody healed in a courthouse." 147 CONG. REC. S6567 (daily ed. June 21, 2001). 
presumably bring with them some degree of allegiance to process integrity as a primary value. The fashioning of external review systems proceeded with little or no input from proceduralists; the legal profession qua legal profession was not involved.

\section{RAMIFICATIONS FOR PROCEDURAL THEORY}

The creation of external review systems represents not only the attempt to substitute due process principles for the erosion of medical authority, but also the attempt to require accountability from powerful private sector entities. External review laws use process itself as a structure of accountability. Increasing accountability to the public from the market is the most self-evident purpose animating the creation of external review systems. One finds this theme repeatedly emphasized in the legislative and political histories of these laws; it speaks directly to the popular outcry against increased reliance on profit as the driving force behind health care delivery systems.

This Part traces the evolution of procedural due process theory. A conceptualization of "process values" arose in the context of disputes between individuals and the government, with an emphasis on the right to an evidentiary hearing prior to the denial or termination of certain benefits. In response to the ascendancy of a degree of corporate power that rivals state power, greater importance attaches to the potential for process mechanisms to foster accountability in the private sector and to promote dialogic exchange among multiple sectors engaged in decision-making. In this new economic environment, attention to accountability and deliberativeness may equal the old paradigm's focus on individual dignitarian concerns. This section concludes with an analysis of how procedural rules and devices perform regulatory functions.

\section{A. Assumptions of the Old Paradigm}

Most procedural theory scholarship has focused on cases like Goldberg and Eldridge, where the question is what process must be accorded the individual who faces adverse action by the state. ${ }^{262}$ In these cases the primary process

262. Jerry L. Mashaw, Due Process in the Administrative State (1985); Frank H. Easterbrook, Substance and Due Process, 1982 SUP. CT. REv. 85, 116-17; Owen M. Fiss, Reason in All Its Splendor, 56 BroOK. L. REv. 789, $792-94$ (1990); Friendly, supra note 43, at 1268-70; Jerry L. Mashaw, Administrative Due Process: The Quest for a Dignitary Theory, 61 B.U. L. REV. 885 (1981) [hereinafter Mashaw, Administrative Due Process]; Mashaw, supra note 55; Rand E. Rosenblatt, Health Care Reform and Administrative Law: A Structural Approach, 88 YALE L.J. 243 (1978); Richard B. Saphire, Specifying Due Process Values: Toward a More Responsive Approach to Procedural Protection, 127 U. PA. L. REv. 111,113 (1978). Scholars who rejected Goldberg as 
concern is restraint of governmental abusiveness, as that abuse manifests itself in the procedures by which government deprives citizens of liberty or property. Grandly put, "the fundamentally important idea towards which the entire constitutional phrase [procedural due process] is reaching . . . is to safeguard the individual from government power that strikes arbitrarily and unfairly."263

Because public sector cases involve an opposition between citizen and state, they are the source of the greatest concern about the quality of interaction that occurs in the process by which state actors determine whether an individual has a legitimate claim or entitlement. Dignitarian values are most at risk when the state is acting against one of its citizens. It is in this context that disrespectful treatment expresses as well as imposes second-class status. ${ }^{264}$

Similarly, the concept of process as values-affirming, independently of substantive law, has been associated primarily with public law issues and largescale litigation, rather than with private, bipolar disputes. ${ }^{265}$ Also, the claims at issue when individuals litigate on theories of recovery derived from public law are most likely to fall within the category that we think of as "rights."266 It is in

"wrongly decided," Richard Epstein, No New Property, 56 BROOK. L. REV. 747, 748 (1990), or
who endorsed the Eldridge criteria, Richard J. Pierce, The Due Process Counterrevolution in the
1990s, 96 COLUM. L. REV. 1973, 1999 (1996), have not been widely followed by other scholars.
263. Cynthia R. Farina, Conceiving Due Process, 3 YALE J.L. \& FEMINISM 189, 213 (1991).
264. Abram Chayes, The Role of the Judge in Public Law Litigation, 89 HARV. L. REV. 1281
(1976); MASHAw, DUE PROCESS IN THE ADMINISTRATIVE STATE, supra note 262, at 23-24, 45-49;
Frank I. Michelman, The Supreme Court and Litigation Access Fees: The Right To Protect One's
Rights, 1973 DUKE L.J. 1153, $1173-74$. For a discussion of "dignitary theories," see MASHAw, DuE
PROCESS IN THE ADMINISTRATIVE STATE, supra note 262, at 162, 172-82; Mashaw, Administrative
Due Process, supra note 255, at 886; Saphire, supra note 262, at 117-25.

265. Owen M. Fiss, The Supreme Court, 1978 Term-Foreword: The Forms of Justice, 93 HARV. L. REV. 1, 30-31 (1979). Ironically, it was on the basis of this distinction that the father of dignitarian process values jurisprudence himself-Justice Brennan - opened the door to the huge increase in the number of cases going into arbitration. In Moses H. Cone Memorial Hospital. $v$. Mercury Construction Corp., 460 U.S. 1 (1983), involving a contract dispute, Justice Brennan's opinion for the Court proclaimed that Congress intended by the Federal Arbitration Act "to move the parties to an arbitrable dispute out of court and into arbitration as quickly and easily as possible." Id. at 22 . The Court later broadened the category of what it considered arbitrable disputes, with Brennan in dissent, but continued to rely on a public policy of facilitating enforcement of arbitration clauses. Rodriguez de Quijas v. Shearson/Am. Express, Inc., 490 U.S. 477, 480-86 (1989).

266. Harry T. Edwards, Alternative Dispute Resolution: Panacea or Anathema?, 99 HARV. L. REv. 668, 671-72 (1986); Harry T. Edwards, Where Are We Heading with Mandatory Arbitration of Statutory Claims in Employment?, 16 GA. ST. U. L. REV. 293, 294, 297 (1999). When government action impinges on rights recognized as carrying special weight, courts are particularly sensitive to procedural norms. See, e.g., M.L.B. v. S.L.J., 519 U.S. 102 (1996) (holding that the 
the interplay between a powerful government and rights-bearing individuals that a decision-making process most significantly generates and reinforces norms.

These traditional procedural due process concerns generated a body of scholarship that largely overlooked the issue of how procedure functions to assure the accountability of private entities. As we have seen, the central theoretical insights of the leading procedure scholars concerned the connection between procedure and individual liberty and dignity, not issues of systemic oversight. For this reason, the procedural due process canon as a whole lacks appreciation of the importance of an analysis that focuses on the accountability of private sector enterprises.

\section{B. The New Primacy of Accountability and Deliberativeness}

Although a new paradigm for procedural theory has not yet crystallized, one can see the emergence of two primary values slighted by the old canon: accountability and deliberativeness. Health process law in general, and external review systems in particular, offer well-defined examples of each.

\section{Accountability}

In health law most of the coverage decisions about whether treatment is medically necessary arise in the private sector. As advocates of patients' bills of rights saw, medical necessity disputes highlight the potential for the use of process in public law efforts to achieve accountability of powerful private entities. This context for analysis of process values resonates with a different line of procedural due process cases, which arose in consumer protection law.

The consumer due process cases typically have involved a dispute in which one of the parties was able to secure a remedy, such as a lien, which was made available by the state without providing adequate procedural safeguards for the other party. The rules of procedure then extant allowed one category of private litigants access to a powerful remedy, thereby systematically depriving another category of litigants of procedural safeguards. The successor to Goldberg v. Kelly in this line of cases is not Eldridge but Fuentes $v$. Shevin, ${ }^{267}$ in which the Court ruled that common law replevin statutes could not authorize the seizure of chattel goods without prior notice and opportunity for a hearing.

The Fuentes line of cases grew out of efforts to reform predatory consumer

state must waive filing fee for indigent appellant when considering the termination of parental rights); Santosky v. Kramer, 455 U.S. 745 (1982) (holding that in parental termination proceeding, state must meet the clear and convincing evidence standard).

267. 407 U.S. 67 (1972). The most recent significant decision in this line of cases is Connecticut v. Doehr, 501 U.S. 1 (1991). 
credit practices. ${ }^{268}$ By analyzing the process aspects of the state's enforcement of judgments against borrowers, the Court addressed the question of the optimal balance between allowing free space for market forces and requiring accountability of powerful private parties. The procedures of adjudication functioned as a structure of accountability. ${ }^{269}$

Grijalva provides an example of health process law operating at the intersection of the progeny of both Goldberg-Eldridge and Fuentes. Under the reasoning of the lower federal courts, the defendant Medicare MCOs were private sector entities which functioned as state actors. After finding that state action existed, the courts' analyses focused on an accountability theme deriving from the interaction between patient and MCO. The Grijalva decisions are silent on Goldberg-like intimations of dignity and participation. They are also not based on Eldridge conclusions that the heightened procedural protections were needed to avert a high risk of erroneous decisions. Plaintiffs won in the lower courts because multiple judges concluded that the private MCO system lacked sufficient accountability. Although this rationale was expressed in individual rights terms, it was fundamentally a systemic argument, not an individual one.

The systemic concern is more oriented toward a focus on the product of procedure, the outcome, than on procedure itself qua procedure. In both Fuentes and Grijalva, plaintiffs challenged procedural rules that exacerbated the imbalance of power between the parties. In both, the existing procedures allowed the stronger party to use law as a tool to diminish the contractual rights held by the weaker party. The procedural due process claim operated to impose accountability and restraint on the stronger party's actions, not solely because of dignitarian harms, but because of what was at stake. It would be naïve to believe that the courts found the stakes to be high purely from the perspective of an individual plaintiff; at issue was the operation of a system.

268. A field research project on predatory practices during the period prior to Fuentes observed that "[p]erhaps the most objectionable practice in consumer credit is that of requiring the consumer who buys on credit to sign an authorization of entry of confession of judgment at the time he makes his purchase." Note, Translating Sympathy for Deceived Consumers into Effective Programs for Protection, 114 U. PA. L. REV. 395, 418 (1966); see also George Brunn, Wage Garnishment in California: A Study and Recommendations, 53 CAL. L. REV, 1214, 1248-49 (1965) (recommending an end to garnishments arising from installment credit contracts and to all pre-judgment garnishments).

269. In subsequent decisions involving garnishment and sequestration, the Court backed away from Fuentes, not unlike the way the Court retreated from Goldberg, by allowing procedural protections other than an evidentiary hearing to suffice prior to seizure, so long as a prompt postseizure hearing was afforded. See, e.g., Mitchell v. W.T. Grant Co., 416 U.S. 600 (1974). However, Fuentes remains good law. N. Ga. Finishing, Inc. v. Di-Chem, Inc., 419 U.S. 601, 608 (1975) (Stewart, J., concurring). 
When the defendant is a government agency, courts can assume that other public systems such as administrative law or legislative oversight will provide accountability. The background assumption of the presence of these other systems makes the accountability function less visible, and leaves courts free to focus on individual dignity and norms of participatory democracy. By contrast, the private sector procedural due process cases highlight the accountability function. And, in today's world of massive concentration of power in private entities, coupled with the privatization trend in which public functions are increasingly being performed in the private sector, the accountability function of procedure will likely become more significant.

Although accountability emerges as the dominant process value in the private party health process cases, dignitarian concerns are not absent. However, dignity norms in private cases differ from those in citizen-government disputes. The right to a hearing is not the only, nor necessarily the most significant, aspect of dignitarian rights. The related right to be told why- to be accorded the respect of a full explanation for the decision - is at least equally compelling. I would call that the deliberative, rather than the dignitarian, aspect of public value process norms. In Grijalva both the district and appeals court treated the right to a full explanation of the reasons for a denial as essential. ${ }^{270}$

\section{Deliberativeness}

Deliberativeness is the second process value which has grown in importance with the decline of the old paradigm. In today's world deliberativeness in decision-making is more important, more of the time, than the right to an evidentiary hearing, especially in a technologically sophisticated field such as health. A well-reasoned explication of the decision in even a relatively simple medical case will necessitate careful review of scientific evidence. In medical necessity reviews, a mandate for explanation is likely to produce a decision of higher quality than would be produced by adversarialism per se.

The value of deliberativeness also synchronizes well with the increasing variety in types of procedural mechanisms, because of its intrinsic flexibility and adaptability. Academic debates about Eldridge treated the values underlying procedural due process as an unvarying package, applicable to any context. Most scholars invoked the right to an evidentiary hearing prior to a deprivation as the

270. Grijalva v. Shalala, 152 F.3d 1115, 1123 (9th Cir. 1998); Grijalva v. Shalala, 946 F. Supp. 747, 757-59 (D. Ariz. 1996). Similarly, reflecting on a large number of similar cases, Judge Weinstein described the pre-Grijalva Medicare system as providing "'gobbledegook' notices" without any real or understandable reason given for the denial. Weinstein, Adjudicative Justice, supra note 17, at 401 . 
benchmark for adequacy, and paid little separate attention to deliberativeness. ${ }^{271} \mathrm{I}$ would argue, however, that in adjudicating complex issues, participation is a secondary value.

Mandating deliberativeness incentivizes decision-makers to obtain full input from the parties, so that they can prepare a fully reasoned and explicated decision. The rationale behind the requirement for a full explanation in every case also creates the strongest foundation for maximum application of a right to a hearing. Using an incentives approach, rather than the mandate for an evidentiary hearing adopted by the Court in Goldberg, would tend to produce hearings in situations where they would actually add the greatest value, and would avoid some of the systemic congestion caused by the Goldberg approach.

This is essentially the argument behind Melvin Eisenberg's deconstruction of the participation norm in adjudication. Building on Lon Fuller's analysis of adjudication as a form of social ordering, ${ }^{272}$ Eisenberg argues that Fuller's "Participation Thesis" - the right of a party in adjudication to participate in the decisional process - breaks down into three norms: (1) "that the adjudicator should attend to what the parties have to say;" (2) that the adjudicator should explain her decision in a manner that responds to the parties; and (3) that the decision "should proceed from and be congruent with" the parties' evidence and arguments. ${ }^{273}$ Eisenberg also argues, however, that some matters are appropriate for the weak responsiveness of a consultative process, in which the decisionmaker is free to draw on sources other than the parties' submissions. ${ }^{274} \mathrm{~A}$ consultative process incentivizes the decision-maker to treat the parties' input seriously, but also leaves her free to use a considerable amount of managerial discretion.

Eisenberg's approach would not satisfy the strongest dignitarians. His willingness to accept a consultative process in Eldridge, which he uses as an

271. The only major exception is Morgan, supra note 44. Frank Michelman notes that "[ $t]$ he individual may have various reasons for wanting to be told why, even if he makes no claim to legal protection, and even if no further participation is allowed him." Frank I. Michelman, Formal and Associational Aims in Procedural Due Process, in Nomos XVIII: DuE Process 126, 127 (J. Rowland Pennock \& John W. Chapman, eds. 1977). The remainder of his essay, however, focused on the right to a hearing. Deliberativeness was also discussed briefly in Mashaw, Administrative Due Process, supra note 262, at 913-915; Robert S. Summers, Evaluating and Improving Legal Processes: A Plea for "Process Values," 60 CoRnell L. Rev. 1, 26 (1974).

272. Lon L. Fuller, The Forms and Limits of Adjudication, 92 HARV. L. REV. 353, $365-72$ (1978).

273. Melvin Aron Eisenberg, Participation, Responsiveness, and the Consultative Process: An Essay for Lon Fuller, 92 HARV. L. REV. 410, 411-12 (1978).

274. Id. at 414-17. 
example of its appropriate use, ${ }^{275}$ makes clear that the consultation concern would not necessarily sustain the right to a hearing. Edmund Pincoffs explained the logic behind prizing a right to hearing over the right to a responsive decisional rationale in the hierarchization of values as "whatever reasoning justifies participation (the opportunity to contest the official's reasoning) will justify revelation to the person affected of the official's reasons." 276 The reverse is not necessarily true.

I would argue, however, that deliberativeness is more important than the right to participate in a hearing, even though that contention skewers a sacred cow of progressive procedural theory. The importance of deliberativeness derives from the fact that its impact matters not just at the level of the individual case, but also at a system level.

Philosopher Jurgen Habermas argued that democracy worked best in an "ideal communication situation," a context in which social consensus as to norms guiding behavior grew out of reasoned exchange, without constraints on either the content of or access to the exchange. ${ }^{277}$ The insight that dialogic exchange rather than individual rights could be the core requirement for fair process applies to external review systems. Habermas's approach reinforces the importance of substantive engagement as a basis for the legitimacy of legal rules.

The value behind the distinct function of deliberativeness derives from the value placed on cultural interconnectiveness, reflected in an insistence on reasoned application of law's coercive power. As with accountability, the concern behind this process value is less with valuation of individuals than with restraint of institutional arrogance and unconstrained economic, as well as governmental, power.

\section{Procedure as Regulation}

We have analyzed accountability as a process value oriented toward the intrinsic fairness of a decision-making procedure, as a kind of policing mechanism to guard against the abuse of procedure itself. Now we examine procedure as a structure of distributive accountability, with a focus more on

275. Id. at 421 .

276. Edmund L. Pincoffs, Due Process, Fraternity, and a Kantian Injunction, in Nomos XVIII: Due Process, supra note 271 at 172, 173.

277. Jurgen Habermas, Between facts and Norms: Contributions to a Discourse THEORY OF LAW AND DEMOCRACY 165-68, 321-28, 360-63 (William Rehg trans., 1996). Lawrence Solum has linked Habermas's theory to issues of procedural justice, noting that the litigation system has many devices (e.g., discovery) which seek to create the conditions that would allow for at least an approximation of the ideal communication situation. Lawrence B. Solum, Procedural Justice, 78 S. CAL. L. REV. 181, 268-271 (2004). 
outcomes of procedure rather than on procedural devices themselves. Assuming a regulatory purpose, ${ }^{278}$ the issue here is how well external review systems operate to bring public norms and values to bear on the allocational choices of what is otherwise a private rationing system.

One can envision the matrix of process values along two dimensions. One dimension is defined by one's concept of the function of adjudication, i.e., whether one prioritizes the role of adjudicatory systems as dispute resolution mechanisms or as expressions of public values. ${ }^{279}$ The second is determined by whether one evaluates such a system by the quality of its outcome or by the quality of its procedures qua procedures. The following chart illustrates the possible array of values:

\begin{tabular}{|c|l|l|}
\hline \multirow{2}{*}{$\begin{array}{c}\text { EVALUATION } \\
\text { BASED ON: }\end{array}$} & \multicolumn{2}{|c|}{ FUNCTION OF ADJUICATION SYSTEM } \\
\cline { 2 - 3 } Quality of Outcome & Accuracy & $\begin{array}{l}\text { Regulatory } \\
\text { Free Market }\end{array}$ \\
\hline \multirow{2}{*}{ Quality of Process } & $\begin{array}{l}\text { Responsiveness } \\
\text { Ethicality (how parties } \\
\text { are treated) } \\
\text { Efficiency }\end{array}$ & $\begin{array}{l}\text { Participation } \\
\text { Dignity } \\
\text { Cost-Effectiveness }\end{array}$ \\
\hline
\end{tabular}

On this understanding, procedure and regulation are not two utterly distinct categories as much as they are reflections of different emphases on function and evaluative norms. Consigning individual coverage decisions to external review panels operated by private companies creates a perfect merger between adjudication and the fundamental paradox of American health care: that both are public goods treated as private commodities, delivered primarily within private

278. Reviewing the literature of pro- versus anti-regulatory arguments is beyond the scope of this Article. The most extensive discussions of decision-making procedures as a mechanism of regulating managed care are in NORMAN DANIELS \& JAMES E. SABIN, SETTING LIMITS FAIRLY: CAN We Learn To Share Medical Resources? 25-66 (2002); and Norman Daniels \& James Sabin, Limits to Health Care: Fair Procedures, Democratic Deliberation, and the Legitimacy Problem for Insurers, 26 PHIL. \& PUB. AfF. 303 (1997) [hereinafter Daniels \& Sabin, Limits to Health Care]. See also Sharona Hoffman, Unmanaged Care: Towards Moral Fairness in Health Care Coverage, 78 IND. L. REV. 659, 693, 711-12 (2003). For a summary of the contentions that regulatory mechanisms for managed care, including external review, will not work, see David A. Hyman, Regulating Managed Care: What's Wrong with a Patient Bill of Rights, 73 S. CAL. L. REV. 221 (2000).

279. David Luban, Settlements and the Erosion of the Public Realm, 83 GEO L.J. 2619, 26222640 (1995). 
systems. ${ }^{280}$ The accretion of coverage decisions operates as a micro-rationing device. Thus, promoting accountability for outcomes is fundamentally a regulatory function. ${ }^{281}$ Because the decisions of external review panels essentially constitute direct allocations of resources, they provide especially clear examples of the blend of adjudication and regulation.

External review systems are related to, but not the same as, privatization, the contracting out of what have typically been government functions or services to private sector profit or non-profit entities. In the realm of procedure, privatization is most visible in the rapid increase in the use of arbitration and other private dispute resolution mechanisms outside of the public courts, ${ }^{282}$ a development which external review laws obviously resemble. In public services privatization generally has led to "new blends of public and private power at all levels of government," and, more fundamentally, a "redefinition of what is public and what is private." 283

Yet external review systems could be labeled equally well either as private sector administrative tribunals or as public law arbitration panels. ${ }^{284}$ They are hybrid mixtures of procedural due process norms and precepts being operationalized and administered by privately owned and operated adjudicators. External review laws have a "publicizing," as well as a privatizing, impact because they extend public law values into the marketplace, farther than due process doctrine itself could reach. ${ }^{285}$ Indeed, in several states the procedures

280. See id. (discussing adjudication as a public good).

281. Martha Minow, Public and Private Partnerships: Accounting for the New Religion, 116 Harv. L. Rev. 1229, 1259 (2003); see also Jody Freeman, Private Parties, Public Functions, and the New Administrative Law, in ReCrafting THE RULE Of LAw: THe Limits of Legal ORder 331, 336 (David Dyzenhaus ed., 1999).

282. Judith Resnik, Migrating, Morphing, and Vanishing: The Empirical and Normative Puzzles of Declining Trial Rates in Courts, 1 J. EMPIRICAL LEGAL STUD. 783, 819-22 (2004); Judith Resnik, For Owen M. Fiss: Some Reflections on the Triumph and the Death of Adjudication, 58 U. MIAMI L. REv. 173, 188-89 (2003); Stephen J. Ware, Default Rules from Mandatory Rules: Privatizing Law through Arbitration, 83 MinN. L. Rev. 703 (1999); Jack B. Weinstein, Some Benefits and Risks of Privatization of Justice Through ADR, 11 OHIO ST. J. ON DiSP. RESOL. 241 (1996).

283. Alfred C. Aman, Jr., Globalization, Democracy, and the Need for a New Administrative Law, 49 UCLA L. REv. 1687, 1688-89 (2002). Aman argues that the scope of this change calls for a new conceptualization of administrative law, which he calls the "neo-corporatism theory of administrative law." Id. at 1703-04.

284. Note that an administrative law judge wrote one of the first comprehensive surveys of these laws. See Craig, supra note 174.

285. Jody Freeman, Extending Public Law Norms Through Privatization, 116 HARV. L. Rev. 1285 (2003). Freeman argues that external review laws are examples of a successful use of publicization. Id. at 1330 . 
accompanying external review are incorporated into the body of state administrative law. ${ }^{286}$

However, although external review entities are more heavily "publicized" than most other private companies, external review laws substantially privatize and deregulate the process for adjudicating complaints that needed care is being denied, if one uses the litigation system or the administrative law model as the benchmark. The trade-off for the ease of streamlined procedures is that external review systems have many fewer protections for the weaker party than public law rules of procedure, as we have seen. On the other hand, they are subject to more regulation than private arbitration generated by contracts, which has become the primary alternative to litigation.

Moreover, in another sense, the degree to which collective norms are being extended by external review laws past their prior reach is more limited than for other such hybrid entities. Before such laws were enacted, patients relied on deference to medical judgment and the fiduciary principle to protect their interests (however naïve the high level of trust may have been). The pre-ERO world was also a pre-MCO world.

It is difficult to assess the extent to which external review systems serve this regulatory or collective accountability function. The device that most effectively renders litigation a regulatory institution is class actions. Yet at least some state regulatory officials describe external review as working so well that it amounts to precisely that: "an ongoing class action." ${ }^{287}$ Of course, the fact that regulators are "overwhelmingly satisfied" with external review ${ }^{288}$ does not necessarily tell us much about its quality as regulation.

The regulated industry reports that it responds to external review decisions in a systemic fashion. Although the data are limited to California, all but one of the plans studied there in 2003 reported that external review decisions influenced their coverage policies. ${ }^{289}$ The impact of industry responsiveness would be heightened by mechanisms for input by patient or consumer organizations. ${ }^{290}$ If meaningful oversight existed on a national scale, external review really might amount to an ongoing class action.

Norman Daniels and James Sabin bring the most optimistic approach to external review. Although not analyzing external review systems specifically, they see the best solution to the problems of distributive justice in managed care

286. See supra text accompanying notes $203,230$.

287. Berman-Sandler, supra note 9 , at 270.

288. Id. at 275 .

289. IMR 2003, supra note 249 , at $4,28-29$.

290. Ongoing consumer advocacy has been particularly strong in Wisconsin. See Trubek, supra note 258 . 
decision-making as the adoption of regulation which is "process focused."291 Daniels and Sabin argue for a combination of the components of accountability discussed in this Article-stated rationales, publicly-accessible decisions, mechanisms for appeal or reconsideration, and some form of regulationtogether with a master norm to guide outcomes: that the rationale must be based on "a reasonable construal of how to meet the medical needs of a covered population under acceptable resource constraints." 292 By emphasizing process over any substantive choices to guide allocational decisions, they hope to avoid the "tragic choices" problem, i.e., the resistance to accepting the need to make such decisions that leads to their being made in disguised ways, beyond public control. ${ }^{293}$ For Daniels and Sabin external review or similar systems can extend deliberative democratic principles to the private institutions in which, for better or worse, much health policy is made. ${ }^{294}$

Using Daniels and Sabin as a benchmark illustrates how far short of that accountability paradigm external review systems currently operate. Again, the fundamental deficiency is the lack of access to the decisions in almost all the states. Without that public resource there cannot be the kind of "institutional reflective equilibrium",295 which they seek, nor any basis for self-conscious acknowledgment of resource constraints, outside of the terms of a contract. Yet since essentially all contracts operate under the same term of "medically necessary," Daniels and Sabin are correct to insist that the contract subject to interpretation in all these cases is, at least to some extent, a social one.

A different kind of accountability relates to quality of care. Although physicians were among the stakeholders who designed external review systems, their primary goals were defensive: to avoid being left holding the bag for both liability $^{296}$ and $\operatorname{cost}^{297}$ when managed care organizations denied authorization for

291. Daniels \& Sabin, Limits to Health Care, supra note 278, at 348.

292. Id. at 307 .

293. Id. at 318-21; see also David Orentlicher, The Rise and Fall of Managed Care: $A$ Predictable "Tragic Choices" Phenomenon, 47 ST. LouIS U. L.J. 412 (2003) (arguing that managed care failed to sustain its strongest cost containment mechanisms because they could not survive public scrutiny as a rationing device, as predicted in GUIDO CALABRESI \& PHILIP BOBBITT, Tragic Choices (1978)).

294. Daniels \& Sabin, Limits to Health Care, supra note 278, at 323-24.

295. Id. at 328.

296. A payor's erroneous refusal to authorize reimbursement for medically necessary care does not absolve the treating physician of professional responsibilities to provide such care. See, e.g., Wickline v. State, 239 Cal. Rptr. 810,819 (Ct. App. 1986). The availability of external review makes that outcome less likely.

297. "[O]ne can view external review requirements as a means to promote physician payment as much as patient care." William M. Sage, Physicians as Advocates, 35 Hous. L. REV. 1529, 1541 
reimbursement of expenses for treatment. Very little attention has been paid, either at the time of enactment or since, to the impact of external review on quality of medical practice, another question which merits further study.

To some extent accountability may be in tension with therapeutic goals. Based on how external review systems are structured, Bill Sage is skeptical that they will improve the quality of care or the degree of trust between doctor and patient. ${ }^{298}$ Sage recommends that review systems be designed based on therapeutic, rather than adversarial, principles, recognizing that while "legal fairness demands due process, often through adversarial advocacy . . . medical fairness . . . demands beneficence and respect for persons." ${ }^{299}$ He favors a mediation approach, especially for patients who have chronic conditions and are thus likely to be repeat users of a review system. ${ }^{300}$

Finally, in some situations involving medical necessity decisions, the value of compassion may justifiably trump all others, including accountability, quality of care, and accuracy. Patients with terminal conditions may seek "last-chance therapies," treatments with little if any proven efficacy which insurance companies can properly deny as experimental. In those instances Kathy Cerminara argues that the protections of external review are largely beside the point. ${ }^{301}$ She advocates the development of personalized therapeutic counseling approaches, using a multi-disciplinary team of professionals. ${ }^{302}$

A bioethics or therapeutic model is perfectly consistent with an emphasis on deliberativeness: Good faith dialogic exchange is central to both, even if accountability plays a lesser role. Yet while it may be impractical or even callous to expect patients in greatly weakened physical condition to navigate appellate or arbitration-style systems, it would be equally naïve to assume that payors will adopt more resource-intensive, and thus more expensive, ways of saying no without some degree of formal or informal pressure. Ultimately, then, the prerequisite for a therapeutic approach is a foundation of accountability.

(1999).

298. Sage, supra note 3 , at 632.

299. Id. at 635 .

300. Id. at 645-46; see also Kathy L. Cerminara, Contextualizing ADR in Managed Care: $A$ Proposal Aimed at Easing Tensions and Resolving Conflict, 33 LOY. U. CHI. L.J. 547 (2002) (evaluating non-litigation options as a way to resolve health care disputes without increasing patient stress). There have been promising results with mediation in the context of malpractice litigation. Edward A. Dauer \& Leonard J. Marcus, Adapting Mediation To Link Resolution of Medical Malpractice Disputes with Health Care Quality Improvement, 60 LAW \& CONTEMP. PROBS. 185 (1997).

301. Kathy L. Cerminara, Dealing with Dying: How Insurers Can Help Patients Seeking LastChance Therapies (Even When the Answer Is "No"), 15 HEALTH MATRIX 285 (2005).

302. Id. 


\section{DO THE MCOS COME OUT AHEAD?}

\section{A. Applying Process Values to External Review Systems}

Thirty years ago Marc Galanter developed a structural framework for analysis of adjudication that divided parties into repeat players and one-shotters, examined how lawyers affected the power dynamics of litigation, and described a number of ways in which the passivity of legal institutions enhanced the power of repeat players. ${ }^{303}$ Galanter's now classic article described a system in which certain classes of parties enjoyed structural advantages. His conclusion about why the "haves" systematically come out ahead emphasized the intrinsic weakness of law as a mechanism for seeking greater social justice, but it can also be read as an indictment of how the litigation system distorts all of the process values that we have discussed, from the utilitarian/efficiency cluster, to the old and new dignitarian norms, to accountability.

External review laws were enacted as part of a backlash against a system in which MCOs were perceived to always come out ahead. The external review systems were designed to mitigate an imbalance between patients and payors (as well as between physicians and payors), and to rectify the operations of a payment process in which decisions were effectively unreviewable because the practical impact of the process was to deny treatment for which reimbursement had not been authorized. When one applies the range of process values to the external review statutes, how well do they measure up?

In this Section I evaluate external review systems by applying utilitarian, dignitarian, and accountability critiques. Although external review falls short in many respects, it retains significant appeal, and may provide a model for forms of independent private review in contexts other than denial of medical claims. At the end of the section, we return to the prospect of health process exceptionalism, but in a new form: to ask not whether the degree of deference should be reinstated, but whether the level of process protections should be elevated.

\section{The Utilitarian Critique}

The greatest appeal of the external review concept is its claim to promote greater efficiency than exists in litigation. The entire procedure is streamlined. In some states appeals can be filed on a web site. ${ }^{304}$ Some states operate consumer

303. Marc Galanter, Why the "Haves" Come Out Ahead: Speculations on the Limits of Legal Change, 9 L. \& SOC'Y REV. 95 (1974).

304. Arkansas, Illinois, Indiana, lowa, Kansas, Kentucky, Missouri, North Carolina, Ohio, Oklahoma, Oregon, Pennsylvania, Texas, and Utah. 
assistance offices, ${ }^{305}$ and lawyers are not required. ${ }^{306}$ The sources of evidence are often specified in statute or regulation. There are deadlines for decisions and shorter deadlines for decisions in cases involving exigent need for care. Medical professionals make the final decisions, as in specialized courts or well-run arbitration systems. The relatively low utilization rates keep down operational costs.

It is difficult to evaluate external review systems on the acid test of how great the risk is of erroneous decisions or, more precisely, how likely external review organizations are to correctly identify wrong decisions by MCOs. Reversal rates alone shed no light on this. ${ }^{307}$ The system lacks sufficient mechanisms either to correct for possible bias or to enhance quality by review of the most difficult, and indeterminate, medical judgments.

In most states there is very little oversight of the external review decisions themselves. In Michigan, where external review decisions must be approved by a state official before they become final, the state agency accepts ninety-eight percent of the ERO decisions. ${ }^{308}$ In California a clinical advisory panel meets quarterly to assess quality of the decision-making. ${ }^{309}$ Most states rely on private accreditation mechanisms to assure quality; ${ }^{310}$ in addition, a national association of independent reviewers has developed. ${ }^{31}$

Several commentators have worried that external review laws, because of the political climate that produced them, are susceptible to bias in favor of consumers. They argue that the goal should be to enforce the actual contract language, as medical necessity is interpreted by the health plan. ${ }^{312}$ Especially problematic from this perspective is the extent to which some states have legislated a definition of medical necessity and/or provided for de novo review of

305. POLLITZ ET AL., supra note 95, at 11-12.

306. However, lawyers tend to get involved when significant amounts are at stake. BermanSandler, supra note 9, at 261-62. Additionally, private companies have begun to market such services. Peter Landers \& Amy Dockser Marcus, You Can Make Them Pay: New Ways To Appeal Make It Easier To Take on Health Insurers and Win, WALL ST. J., Sept. 17, 2002, at D1; Barbara Martinez, Aetna Insiders Now Advocate for Patients, WALL ST. J., Jan. 28, 2003, at B1.

307. See supra text accompanying note 254

308. Berman-Sandler, supra note 9, at 259.

309. Cal. Health \& SafeTy Code $\S 1347.1(03)$ (West 2000).

310. Berman-Sandler, supra note 9, at 239.

311. See National Association of Independent Review Organizations, http:/www.nairo.org (last visited Dec. 4, 2005).

312. Hyman, supra note 278, at 250; Aaron Seth Kesselheim, Comment, What's the Appeal? Trying To Control Managed Care Medical Necessity Decision-Making Through a System of External Appeals, 149 U. PA. L. REv. 873, 915-16, 918-19 (2001); Sloan \& Hall, supra note 4, at 193. 
such determinations. ${ }^{313}$ Some support for their concern is evident in the request by health plans in California for an agency that will review the independent reviewers. $^{314}$

Market asymmetries, especially in access to information, suggest that the question is more complicated than the possibility of bias in one direction or another. Should consumers/patients be held to the terms of a bargain, or as Wendy Mariner argued, should the "health plan's obligations . . . be those that reasonable managed care organizations, and reasonable patients, with equal bargaining power and good information, would expect as fair and reasonable for the stated price"? ${ }^{315}$ If the latter is accurate-and it probably is more consistent with what enrollees in a group plan, who had no role in negotiating the contract, believe they are getting-then standards for reasonableness imposed through publicly accountable institutions such as the legislature should be acceptable as methods of perfecting the market.

In either case, it may nonetheless be true that one could due process to death a useful reform by adding more of the indicia of a litigation system-such as more extensive discovery or hearings-to the external review systems. Such reforms could lead to nothing more than procedural formalism without functional improvement. As utilitarians would point out, humanistic process values can be lost in systemic sclerosis.

\section{The Dignity and Deliberativeness Critique}

As effectuators of traditional dignity values, external review systems have serious deficiencies. Few states provide opportunities for patients to present their case, other than by the submission of appeals forms or paper records. ${ }^{316}$ Dignitarians would argue that even though hearings would delay decisions, patients could decide whether to make that trade-off or not, depending on their most significant concerns.

The traditional dignitarian critique is less applicable to external review than to other contexts, however. External review boards are usually assessing the competing recommendations of two (or more) physicians. Thus the voice for the weaker party that would be most significant in the great majority of cases would be that of the physician recommending the treatment that the health plan had denied. This gives a different valence to norms of individual dignity and the

313. See supra text accompanying notes 174-182.

314. IMR 2003, supra note 249, at 29.

315. Wendy K. Mariner, Standards of Care and Standard Form Contracts: Distinguishing Patient Rights and Consumer Rights in Managed Care, 15 J. CONTEMP. HEALTH L. \& POL'Y 1, 27, 43 (1998).

316. POLLITZ ET AL., supra note 95 , at 20. 
collective ideal of participation. Some form of consultation between the external reviewers and the physician(s) who recommended a particular treatment could well enhance accuracy, however, even if there was little or no gain to dignity.

If one separately examines the deliberativeness critique, external review systems receive at best weak reviews. Presumably all EROs state reasons for their decisions, but it is difficult to know with how much clarity or whether the reasons are communicated in terms that the average layperson would understand. Data from California are not encouraging. The 2003 audit of the system found that patients, their physicians, and the health plans whose denials had been overturned all wanted more information and explanation of the rationales of the external reviewers. ${ }^{317}$ The fact that such problems plague the system in California, which has more transparency than in any other state, does not augur well for the quality of deliberativeness nationwide.

\section{The Accountability Critique}

As mechanisms of accountability designed to prevent abusive use of procedures by more powerful parties, external review systems are also problematic. If the utilitarian critique evinces concern with bias in favor of consumers, an accountability model focuses attention on the risk of bias against consumers. External review laws create advantages for repeat-player MCOs in multiple ways. As a threshold matter, there are wide disparities among the states on three important indicia of accountability: (1) independence of the external reviewer; ${ }^{318}$ (2) practical access to the system; $;{ }^{319}$ and (3) public availability of the decisions being rendered. ${ }^{320}$ All of these factors operate to exclude or disable the one-shot patient party, even if she is represented by counsel.

One additional problematic characteristic of all external review systems is their individuation and disjoinder effects. All cases are individual cases, and can only be litigated as such. There is no possibility that a series of similar denials of care, for example, can be joined either in the remedy of seeking injunctive relief or in the form of constituting a class action. Because of the way that decisions about what is medically necessary function as a micro-rationing system, this individuation and disjoinder is an especially significant process cost, more so than in more routine consumer cases such as Fuentes.

317. IMR 2003, supra note 249 , at 3-5. Of the unsuccessful appellants, none said they understood the reasoning of the IRO. Id. at 32.

318. See supra text accompanying notes $218-223$.

319. See supra text accompanying notes $247-252$.

320. See supra text accompanying notes 228-231. Legitimate concerns about the confidentiality of medical information can be accommodated by the redaction of personal identifiers, as occurs in the three states that make decisions public. 
Possible remedies obtainable from external review are quite limited, but that trade-off is central to the function of the system. If successful complainants could recover monetary damages, for example, the speed and informality would have to be sacrificed. Moreover, patients can usually elect to sue without going through external review or after they lose an appeal. ${ }^{321}$ But external review systems would be better equipped to prevent abusive tactics by the more powerful party if clear penalties existed for conduct such as excessive delay or refusal to produce documents. In some states the law authorizes what is in essence a judgment by default in such situations. ${ }^{322}$ Most state laws, however, lack these self-policing mechanisms.

To the extent that one can judge fairness by the perception of fairness, the few data which exist are not reassuring. In a representative sample study, only about half of patients who went through external review in California expressed confidence that their individual medical status had been considered, that the review had been fair and impartial, or that the reviewers had thoroughly considered the available scientific information. ${ }^{323}$ Their assessment was almost totally contingent on outcome; those who had prevailed found the process fair, those who had lost found it unfair. ${ }^{324}$ Since the hallmark of legitimacy for a process system is that those who do not prevail nonetheless accept the procedure as fair ${ }^{325}$ there appears to be a serious problem in at least the public's belief that external review achieves the basic accountability function that produced these laws in the first place: protecting individual patients against MCO abuses. ${ }^{326}$

Too often, external review systems represent missed opportunities for accountability. Even if they provide a reasonable degree of protection against improper denials of care or reimbursement, they do not even seriously attempt to enhance overall quality of care by sharing information with physicians conscientiously attempting to solve difficult medical problems. Nor do they offer a venue in which distributional concerns might be opened up for greater public deliberativeness. In these respects, they are strongly aligned with the goals of individualized dispute resolution, rather than with any broader functions.

\section{External Review as Creation of a New Model}

A final consideration in applying the metric of process values to external

321. See supra text accompanying note 232 .

322. See, e.g., W. VA. CODE ANN. \$33-25C-6(j) (LexisNexis 2003).

323. IMR 2003, supra note 249 , at 18.

324. Id. at 32.

325. TYLER, supra note 93, at 79-80, 166-67.

326. To some extent, the dissatisfaction may stem from the lack of a hearing or other opportunity for patient participation. See supra text accompanying notes 92-93. 
review systems is the question of whether they will themselves become a new marker for minimally acceptable procedural due process, not only in the private marketplace but also, in a kind of doctrinal blowback, in public law as well. ${ }^{327}$ Litigating in the shadow of arbitration came to influence many aspects of court procedure, ${ }^{328}$ and reactions to due process shortcomings in private arbitration are now forcing it to include more procedural protections. ${ }^{329}$ Private external review companies will seek larger markets, and their efficiency and low operating costs could make them a model for resolving non-managed care disputes, setting off a competitive dynamic similar to that between litigation and arbitration. Establishment of an independent review process specifically for physicians has become one of the terms of settlement in class action suits against large insurance companies, in which doctors alleged that the insurers repeatedly underpaid them. $^{330}$

In the end, with so little empirical data on how external reviews are actually operating, we do not yet know whether they will provide appropriate and sufficient relief for patients or whether the MCOs will always come out ahead. Alternatives to litigation certainly are not insulated from the same problems that Galanter identified in the court system. ${ }^{331}$ The promise of external review systems is that they will be streamlined but careful, efficient but fair, providing accountability without being cumbersome. If they live up to that standard, they may emerge as the FedEx of adjudication systems, leading the older public sector institutions (i.e., courts) to look to them for high quality customer service in areas

327. See Robert Pear, Bush Pushes Plan To Curb Medicare Appeals, N.Y. Times, Mar. 16, 2003, at Al (discussing proposal to substitute arbitrators for administrative law judges to hear second-level appeals of denials of claims for services or payment and to add requirement that deference be given to agency policies, as well as to statutes and regulations).

328. For discussions of the impact on litigation of arbitration and other alternatives, see Kenneth S. Abraham \& J.W. Montgomery III, The Lawlessness of Arbitration (Univ. of Va. School of Law, Public Law Research Paper No. 02-09, 2002), available at http://ssrn.com/abstract=353340; and Bryant Garth, From Civil Litigation to Private Justice: Legal Practice at War with the Profession and Its Values, 59 BROOK. L. Rev. 931, 948 (1993).

329. See, e.g., Hooters of Am., Inc. v. Phillips, 39 F. Supp. 2d 582, 618-20 (D.S.C. 1998), aff'd and remanded, 173 F.3d 933, 938-40 (4th Cir. 1999); Armendariz v. Found. Health Psychcare Servs., Inc., 6 P.3d 669, 682-89 (Cal. 2000). The American Bar Association Section on Dispute Resolution has created a model due process protocol for mediation and arbitration in health care disputes. Margaret M. Harding, The Limits of the Due Process Protocols, 19 OHIO ST. J. ON DISP. RESOL. 369, 405-08 (2004).

330. Ceci Connolly, Insurer Agrees To Pay Doctors $\$ 198$ Million, WASH. POST, July 12, 2005 , at $\mathrm{A} 2$.

331. See Carrie Menkel-Meadow, Do the "Haves" Come out Ahead in Alternative Judicial Systems?: Repeat Players in ADR, 15 OHIO ST. J. ON DisP. RESOL. 19, 32-53 (1999). 
involving scientific or technical expertise. Or they may never amount to more than "low-end justice for the rank and file." 332 Only time and more data will tell us the answer.

\section{B. Health Process Exceptionalism Redux}

We began with the story of health process exceptionalism: how deference dominated due process. External review laws bring us full circle to the questions behind exceptionalism. Should the exigencies of managed care practice lead us to conclude that health process should be different after all, by becoming more medicalized? Bill Sage's argument for models of therapeutic mediation would lead to structures even less tied to procedural norms than before. Or, with medical deference now largely abandoned, should there be greater due process protections than the current norm, in order to enhance the accountability function of external review?

One marker of the friction between the exceptionalist or medical model and the legal model is the divergence between the professions in how they conceptualize the role of prior case-specific decisions. The professional culture of medicine emphasizes the importance of change geared to improving the quality of care as much as the goal of adherence to norms based on current knowledge. Dan Fox describes medical culture as granting authority to "physicians, armed with the latest knowledge, and not [bound by] precedent.",333 A core value of the legal system, by contrast, is " $[t]$ o stand by things decided, and not to disturb settled points." 334 Not only does precedent as such lack value in the methodology for production of medical knowledge, but payors may be legitimately apprehensive that decisions in highly unusual cases could create mandates.

For these reasons precedent could not operate in external review systems in the way that it does in other adjudication systems. Adopting a concept of binding precedent would disadvantage patients and society as well as flout the norms of medicine. But the misfit between medical and legal concepts of precedent does not justify blocking the gains that would ensue from the greater transparency built into making decisions accessible to the public. Knowledge of outcomes in

332. Bryant G. Garth, Tilting the Justice System: From ADR as Idealistic Movement to a Segmented Market in Dispute Resolution, 18 GA. ST. U. L. REV. 927, 932 (2002).

333. Fox, supra note 88, at 213. Bill Sage concurs, arguing that gaps in medical knowledge cannot be filled by "the mortar of . . . interpretation," as is done with case law that builds upon case law, but must await moments of new scientific discovery to establish the validity of evolving clinical practices. Sage, supra note 297, at 1604.

334. BLACK'S LAW DiCTIONARY 1414 (7th ed. 1999) (definition of stare decisis et non quieta movere). 
prior similar cases provides a baseline, offering guidance to patients, protection against the potential flaws of medical decision-making, ${ }^{335}$ and fulfillment of deliberativeness as a dignitarian process value.

The availability of the body of decisions is fundamental to medical transparency, even if precedent as lawyers understand it may prove counterproductive. The approach to evaluating external review as a regulatory mechanism should focus on aggregate accountability that includes a range of measures, from procedural audits to data-driven analysis. Oversight, too, can be innovative. $^{336}$ Thoroughly public or completely transparent systems are not necessary for legitimacy and fairness in these decisions, but accountability to the public is.

\section{CONCLUSION}

In a rare example of legislative convergence, forty-two jurisdictions in the United States have adopted external review laws, almost all in less than a decade. These laws represent both a new paradigm in health law and a new generation of adjudication mechanisms. Where the two fields intersect, external review furnishes the latest chapter in a long-running saga of tension between deference to physicians and the norms of procedural due process.

External review systems combine private judging companies and standards set by public law. They illustrate both how due process norms are manifest in privatized dispute resolution and how hybrid public-private networks function as a key mechanism for adjudication. External review represents a new model for resolving disputes about whether care is medically necessary, and may foreshadow similar models in other fields.

In external review systems, the dominant process norms are accountability and deliberativeness, rather than a model of rights associated with entitlement to a hearing. The purpose of eliciting dialogic engagement combines with the use of procedure itself as regulation. However, those goals cannot be attained or even confidently measured without greater transparency than now exists in these new systems.

335. See supra text accompanying note 61 .

336. See Louise Trubek's call for "stepping outside the regulatory box." Trubek, supra note 258, at 583-84. 